\begin{tabular}{ll}
\hline Richmond Journal of Law \& Technology & Volume XXIII, Issue 2 \\
\hline
\end{tabular}

\title{
Resisting the Resistance: Resisting Copyright And Promoting Alternatives
}

\author{
Cite as: Giancarlo F. Frosio, Resisting the Resistance: Resisting Copyright \\ and Promoting Alternatives, 23 Rich. J.L. \& Tech. 4 \\ (2017), http://jolt.richmond.edu/index.php/volume23_issue2_frosio/.
}

\author{
Giancarlo F. Frosio
}

\begin{abstract}
This article discusses the resistance to the Digital Revolution and the emergence of a social movement "resisting the resistance." Mass empowerment has political implications that may provoke reactionary counteractions. Ultimately -as I have discussed elsewhere-resistance to the Digital Revolution can be seen as a response to Baudrillard's call to a return to prodigality beyond the structural scarcity of the capitalistic market economy. In Baudrillard's terms, by increasingly commodifying knowledge and expanding copyright protection, we are taming limitless power with artificial scarcity to keep in place a dialectic of penury and unlimited need. In this paper, I will focus on certain global movements that do resist copyright expansion, such as creative commons, the open access movement, the Pirate Party, the A2K movement and cultural environmentalism. A nuanced discussion of these campaigns must account for the irrelevance of copyright in the public mind, the emergence of new economics of digital content distribution in the Internet, the idea of the death of copyright, and the demise of traditional gatekeepers. Scholarly and market alternatives to traditional copyright merit consideration here, as
\end{abstract}

- Senior Researcher and Lecturer, Centre for International Intellectual Property Studies (CEIPI), University of Strasbourg; Non-Resident Fellow, Stanford Law School, Center for Internet and Society. S.J.D., Duke University School of Law, Durham, North Carolina; LL.M., Duke University School of Law, Durham, North Carolina; LL.M., Strathclyde University, Glasgow, UK; J.D., Università Cattolica del Sacro Cuore, Milan, Italy. The author can be reached at gcfrosio@ceipi.edu. 


Richmond Journal of Law \& Technology Volume XXIII, Issue 2
well. I will conclude my review of this movement "resisting the
resistance” to the Digital Revolution by sketching out a roadmap for
copyright reform that builds upon its vision.

\section{INTRODUCTION}

[1] In The Creative Destruction of Copyrights, Raymond Ku applied for the first time the wind of creative destruction-made famous by Joseph Schumpeter - to the Digital Revolution. ${ }^{1}$ According to Schumpeter, the "fundamental impulse that sets and keeps the capitalist engine in motion" is the process of creative destruction which "incessantly revolutionizes the economic structure by incessantly destroying the old one, incessantly creating a new one." 2 Traditional business models' resistance to technological innovation unleashed the wind of creative destruction. Today, we are in the midst of a war over the future of our cultural and information policies. The preamble of the Washington Declaration on Intellectual Property and the Public Interest explains the terms of this struggle:

[t]he last 25 years have seen an unprecedented expansion of the concentrated legal authority exercised by intellectual property rights holders. This expansion has been driven by governments in the developed world and by international organizations that have adopted the maximization of intellectual property control as a fundamental policy tenet. Increasingly, this vision has been exported to the rest of the world. Over the same period, broad coalitions of civil society groups and developing country governments have emerged to promote more balanced approaches to intellectual property protection. These coalitions have supported new initiatives to promote innovation and creativity, taking advantage of the opportunities offered by new technologies. So far, however, neither the substantial

\footnotetext{
${ }^{1}$ See Raymond S. R. Ku, The Creative Destruction of Copyrights: Napster and the New Economics of Digital Technology, 69 U. CHI. L. REV. 263 (2002).

2 JoSEPH A. SCHUMPETER, CAPITALISM, SOCIALISM, AND DEMOCRACY 82-83 (Harper and Row 1975) (1942).
} 


Richmond Journal of Law \& Technology $\quad$ Volume XXIII, Issue 2

risks of intellectual property maximalism, nor the benefits of more open approaches, are adequately understood by most policy makers or citizens. This must change if the notion of a public interest distinct from the dominant private interest is to be maintained. ${ }^{3}$

[2] The underpinnings of this confrontation extend to a broader discussion over the cultural and economic tenets of our capitalistic society, freedom of expression and democratization.

\section{RESISTANCE AND RESISTING THE RESISTANCE}

[3] Since the origins of the open source movement, mass collaboration has been envisioned as an instrument to create a networked democracy. ${ }^{4}$ The political implications of mass collaboration in terms of mass empowerment are relevant to the ideas of freedom and equality. Usergenerated mass collaboration has promoted decentralization and autonomy in our system of creative production. ${ }^{5}$ Internet mass empowerment might spur enhanced content production's democratization from which political democratization might follow. ${ }^{6}$ As Clay Shirky described, open networks reverse the usual sequence of filter, then publish, by making it easy to

\footnotetext{
${ }^{3}$ The Washington Declaration on Intellectual Property and the Public Interest, INFOJUSTICE.ORG (August 25-27, 2011), http://infojustice.org/washington-declaration$\mathrm{html}$, archived at https://perma.cc/W9U8-LUNA; See also Sebastian Haunss, The Politicisation of Intellectual Property: IP Conflicts and Social Change, 3 W.I.P.O.J. 129 (2011).

${ }^{4}$ See Douglas Rushroff, Open Source Democracy 46-62 (DEMOS 2003); see also Yochai Benkler, Coase's Penguin, or, Linux and The Nature of the Firm, 112 YALE L. J. 369, 371-372 (2002).

${ }^{5}$ See id. at 374.

${ }^{6}$ See Yochai Benkler, A Free Irresponsible Press: Wikileaks and the Battle over the Soul of the Networked Fourth Estate, 46 HARVARD CIVIL RIGHTS-CIVIL LIBERTIES L. REV. 3112011 (discussing the democratic functionality of Wikileaks).
} 
publish, then filter. ${ }^{7}$ Minimizing cultural filtering empowers sub-cultural creativity and thus cultural distinctiveness and identity politics. ${ }^{8}$

[4] Mass empowerment, however, triggers reactionary effects. Change has always unleashed a fierce resistance from the established power, both public and private. It did so with the Printing Revolution. ${ }^{9}$ It does now with the Internet Revolution. For public power, the emergence of limitless access, knowledge, and therefore freedom, is a destabilizing force that causes governments to face increasing accountability and therefore relinquish a share of their power. ${ }^{10}$ Through mass empowerment, the Internet, and global access to knowledge, private power sees the dreadful prospect of having to switch from a top-down to a bottom-up paradigm of consumer consumption. ${ }^{11}$ Much to the dismay of the corporate sector, the Internet presents serious obstacles for the management of consumer behavior. ${ }^{12}$ As Patry noted, "“[c]opyright owners' extreme reaction to the Internet is based on the role of the Internet in breaking the vertical monopolization business model long favored by the copyright industries." 13 In combatting this breakdown, the copyright industries have

${ }^{7}$ See Clay Shirky, Cognitive Surplus: Creativity And GEnERosity in a Connected Age 81-109 (The Penguin Press 2010).

${ }^{8}$ See, e.g., Rebecca Tushnet, Payment in Credit: Copyright Law and Subcultural Creativity, 70 LAW \& CONTEMP. PROBS. 138 (2007); see also THEORIZING FANDOM: FANS, SubCUlTURE AND IDENTITY (Alexander Alison \& Harris Cheryl eds., Hampton Press 1997); see generally ANDREW L. SHAPIRO, THE CONTROL REVOLUTION: HOW THE InTERnet is PutTing Individuals In CHARge AND CHANGING THE World WE KNOW (Public Affairs 1999).

${ }^{9}$ See e.g., Denise E. Murray, Changing Technologies, Changing Literacy Communication, 2 LANGUAGE LEARNING \& TECH. 43, (2000).

${ }^{10}$ See e.g., William PAtry, Moral PANICS AND the COPYRIGHT WARS 27 (Oxford U. Press 2009) (explaining the impossibility of governments prosecuting all violations of copyright infringement in a peer-to-peer network).

${ }^{11}$ See id at 27-28.

${ }^{12}$ See id at 25-27.

${ }^{13} I d$. at 5. 


Richmond Journal of Law \& Technology $\quad$ Volume XXIII, Issue 2

waged "...[t]he Copyright Wars [which] are an effort to accomplish the impossible: to stop time, to stop innovation, to stop new ways of learning and new ways of creating." ${ }^{\text {"14 }}$ In particular, the steady enlargement of copyright becomes a tool used by reactionary forces willing to counter the Digital Revolution. ${ }^{15}$ From a market standpoint, stronger rights allow the private sector to enforce a top-down consumer system. ${ }^{16}$ The emphasis of copyright protection on a permission culture favors a unidirectional market, where the public is only a consumer, passively engaged to pay-per use or else stop using copyrighted works. ${ }^{17}$ From a political standpoint, a tight control on reuse of information prevents mainstream culture from being challenged by alternative culture. ${ }^{18}$ Copyright law empowers mainstream culture and marginalizes minority alternative counter-culture, therefore relenting any process leading to a paradigm shift. ${ }^{19}$

[5] From a broader socio-economic perspective, there is also a more systemic explanation to the reaction facing the emergence of the networked information society. Baudrillard's arguments might explain the reaction to the Digital Revolution-driving cultural goods' marginal cost

\footnotetext{
${ }^{14}$ See PATRY, supra note 10 at 39.

${ }^{15}$ See Copyright In The Digital Era, Building Evidence For Policy, NATIONAL ACADEMIES (2013), http://sites.nationalacademies.org/cs/groups/pgasite/documents/webpage/pga_085415.pdf , archived at https://perma.cc/757P-QXY2.

${ }^{16}$ See PATRY, supra note 10 at 26.

${ }^{17}$ See id.

${ }^{18}$ See Benkler, Coase's Penguin, or, Linux and The Nature of the Firm, supra note 4 at 400-401.

${ }^{19}$ I have discussed the effects of copyright expansion on semiotic democracy-with a comprehensive review of literature on point-in a previous piece of mine to which I remand. See generally Giancarlo F. Frosio, Rediscovering Cumulative Creativity from the Oral Formulaic Tradition to Digital Remix: Can I Get a Witness? 13(2) J. MARSHALl REV. INTELL. PROP. L. 341 (2014), https://papers.ssrn.com/sol3/papers2.cfm?abstract_id=2199210, archived at . https://perma.cc/MUM8-B9H8.
} 
Richmond Journal of Law \& Technology $\quad$ Volume XXIII, Issue 2

of distribution and reproduction close to zero. ${ }^{20}$ Copyright law might become an instrument to protect the capitalistic notion of consumption and perpetuate a system of artificial scarcity. As the Digital Revolution turns consumers into users, and then creators, it defies the very notion of consumer society. It turns the capitalistic consumer economy into a networked information economy, which is characterized by a sharing and gift economy. So, for the socio-economic consumerist paradigm not to succumb, the limitless power of peer and mass collaboration must be tamed by the artificial scarcity created by copyright law. Ultimately, resistance to the Digital Revolution can be seen as a response to Baudrillard's call for a return to prodigality beyond the structural scarcity of the capitalistic market economy. ${ }^{21}$ The Internet and networked peer collaboration may represent a return to "collective 'improvidence' and "prodigality" and their related "real affluence." 22 New Internet dynamics of exchange and creativity might answer in the positive Baudrillard's question whether we will "... return, one day, beyond the market economy, to prodigality[.] ${ }^{23}$ In Baudrillard's terms, by increasingly commodifying knowledge and expanding copyright protection, we are taming limitless power with artificial scarcity to keep in place a "dialectic of penury" and "unlimited need." ${ }^{24}$ Therefore, the reaction to the Internet revolution may be construed as a gatekeepers' attempt to keep their privileges in place as they thrive within a paradigm that builds the need of production-and overproduction —over an obsession with artificial scarcity.

\footnotetext{
${ }^{20}$ See generally Giancarlo F. Frosio, User Patronage: The Return of the Gift in the “Crowd Society”, 2015(5) MicH. ST. L. ReV. 1983, 2036-2039 (2015), https://papers.ssrn.com/sol3/papers2.cfm?abstract_id=2659659, archived at https://perma.cc/UEW8-C9KR (discussing Baudrillard's categories as applied to cyberspace and the Digital Revolution).

${ }^{21}$ See Jean Baudrillard, The Consumer Society: Myths AND Structures 66-68 (Mike Featherstone ed., Sage Publ'ns 1998) (1970).

${ }^{22} I d$. at 67.

${ }^{23} I d$. at 68 .

${ }^{24} I d$. at 67.
} 


Richmond Journal of Law \& Technology $\quad$ Volume XXIII, Issue 2

[6] In the past few years, a global movement grew under the understanding that the digital networked environment must be protected from external manipulations intended to stop exchange and re-instate scarcity. In this sense, resistance to copyright over-expansion can be understood as a cultural movement "resisting the resistance" to the Digital Revolution. ${ }^{25}$ Francis Gurry, Director General of the World Intellectual Property Organization, gives a good explanation of these resistance mechanics.

[7] Gurry noted that:

...the central question of copyright policy...implies a series of balances: between availability, on the one hand, and control of the distribution of works as a means of extracting value, on the other hand; between consumers and producers; between the interests of society and those of the individual creator; and between the short-term gratification of immediate consumption and the long-term process of providing economic incentives that reward creativity and foster a dynamic culture. Digital technology and the Internet have had, and will continue to have, a radical impact on those balances. They have given a technological advantage to one side of the balance, the side of free availability, the consumer, social enjoyment and short-term gratification. History shows that it is an impossible task to reverse technological advantage and the change that it produces. Rather than resist it, we need to accept the inevitability of technological change and to seek an intelligent engagement with it. There is, in any case, no other choice - either the copyright system adapts to the natural advantage that has evolved or it will perish. ${ }^{26}$

\footnotetext{
${ }^{25}$ Eben Moglen, Professor, Speech at the Law of the Common Conference at Seattle University: Free and Open Software: Paradigm for a New Intellectual Commons (March 13, 2009) (transcript available at http://en.wikisource.org/wiki/Free_and_Open_Software:_Paradigm_ for_a_New_Intellectual_Commons), archive $\bar{d}$ at http://perma.cc/J78D-R8AG.

${ }^{26}$ Francis Gurry, Dir. Gen. of the World Intellectual Prop. Org., Speaker at the Blue Sky Conference: Future Directions in Copyright Law at Queensl. Univ. of Tech., Brisbane,
} 
Richmond Journal of Law \& Technology

Volume XXIII, Issue 2

[8] In the dedication to the Expositiones in Summulas Petri Hispaniprinted around 1490 in Lyons - the editor, Johann Trechsel, announced: "[i]n contrast to xylography, the new art of impression I am practi[c]ing ends the career of all the scribes. They have to do the binding of the books now." 27 Similarly, in the digital era, distributors' roles and functions might be redefined.

One of the key lessons in the gradual shift in market power in the entertainment industry these days is that the power of the old gatekeepers is declining, even as the overall industry grows. The power, instead, has definitely moved directly to the content creators themselves. Creators no longer need to go through a very limited number of gatekeepers, who often provide deal terms that significantly limit the creator's ability to make a living. ${ }^{28}$

\footnotetext{
Austl. (February 25, 2011) (transcript available at http://www.wipo.int/aboutwipo/en/dgo/speeches/dg_blueskyconf_11.html, 1-2), archived at https://perma.cc/KM6G-6WCL (emphasis added).

${ }^{27}$ See Uwe Neddermeryer, Why were there no Riots of the Scribes? First Result of a Quantitative Analysis of the Book-production in the Century of the Gutenberg, 31 Gazette Dulivre Medieval 1, at 4-7 (1997) (discussing that at the time of the printing revolution, the resistance to the new technology was little. Only few protests from scribes were recorded throughout Europe. In fact, the only reported protests in Genoa in 1472, in Augsburg in 1473, and in Lyon in 1477. Reconversion from old to new jobs was smooth. A variety of new jobs was created and there are no indications of unemployment or poverty suffered by any part of society due to the introduction of the new technology.); see also Peter Burke, The ItAlian RenAissance: Culture AND SOCIETY IN ITALY, at 71 (Princeton U. Press 1999) (noting the adaptability of several scribes, who became printers themselves); see also CYPRIAN BLAGDEN, THE STATIONERS' COMPANY: A HiSTORY, 1403-1959, at 23 (Stanford U. Press 1977) (1960) (reporting that "there is no evidence of unemployment or organized opposition to the new machines" in England). Quite the contrary, in the last quarter of the fifteenth century more money was spent on books that any time before.

${ }^{28}$ Michael Masnick \& Michael Ho, The Sky is Rising: A Detailed Look at the State of the Entertainment Industry, FLOOR 64, 5 (January 2012), http://www.techdirt.com/skyisrising, archived at https://perma.cc/42WV-N9CC.
} 


Richmond Journal of Law \& Technology $\quad$ Volume XXIII, Issue 2

[9] Instead, “...a major new opportunity has opened up, not for gatekeepers, but for organizations that enable artists to do the different things that the former gatekeeper used to do-but while retaining much more control, as well as a more direct connection with fans. ${ }^{29}$ As discussed at length in another piece of mine, ${ }^{30}$ multiple emerging organizations are enabling a direct discourse between artists and users (e.g. Kickstarter, TopSpin or Bandcamp. $)^{31}$ As a consequence, traditional cultural intermediaries might be forced to give up their Ancien Régime's privileges, causing further resistance to change. In the words of Nellie Kroes, European Commission Vice-President for the Digital Agenda,

[a]ll revolutions reveal, in a new and less favourable light, the privileges of the gatekeepers of the "Ancien Régime." It is no different in the case of the internet revolution, which is unveiling the unsustainable position of certain content gatekeepers and intermediaries. No historically entrenched position guarantees the survival of any cultural intermediary. Like it or not, content gatekeepers risk being sidelined if they do not adapt to the needs of both creators and consumers of cultural goods...Today our fragmented copyright system is ill-adapted to the real essence of art, which has no frontiers. Instead, that system has ended up giving a more prominent role to intermediaries than to artists. It irritates the public who often cannot access what artists want to offer and leaves a vacuum which is served by illegal content, depriving the artists of their welldeserved remuneration. And copyright enforcement is often entangled in sensitive questions about privacy, data protection or even net neutrality. It may suit some vested interests to avoid a debate, or to frame the debate on copyright in moralistic terms that merely demonise millions of citizens. But that is not a sustainable approach...My

\footnotetext{
${ }^{29} I d$.

${ }^{30}$ See Frosio, supra note 20, at 2039-2046.

${ }^{31}$ See Masnick \& Ho, supra note 28 at 5-6.
} 


Richmond Journal of Law \& Technology
$\begin{aligned} & \text { position is that we must look beyond national and } \\ & \text { corporatist self-interest to establish a new approach to } \\ & \text { copyright. }\end{aligned}$

\section{Resisting Copyright (At Zero MARginal Cost) AND Promoting Alternatives}

[10] In the aftermath of the legal battles targeting P2P platforms (such as ThePirateBay), the Pirate Party "emerge[d] [in Sweden] to contest elections on the basis of the abolition or radical reform of intellectual property, in general, and copyright, in particular. The platform of the Pirate Party proclaims that ' $[\mathrm{t}]$ he monopoly for the copyright holder to exploit an aesthetic work commercially should be limited to five years after publication. A five years copyright term for commercial use is more than enough.",33 "Non-commercial use should be free from day one". 34 The Pirate Party saw large successes at its first electoral appearances both in Sweden and Germany and similar political groups have now formed in other countries. ${ }^{35}$ The Pirate Party serves as an "extreme expression [of] the sentiment of distaste or disrespect for intellectual property on the Internet". ${ }^{36}$ However, even the Economist has argued that copyright

\footnotetext{
${ }^{32}$ Neelie Kroes, European Commission Vice-President for the Digital Agenda, A Digital World of Opportunities at the Forum d'Avignon - Les Rencontres Internationales de la Culture, de l'Économie et des Medias, (November 5, 2010), available at http://europa.eu/rapid/press-release_SPEECH-10-619_en.htm, archived at https://perma.cc/ERN7-5TN4.

33 See Gurry supra note 26.

${ }^{34}$ Copyright Perspectives: Past, Present And Prospect vii (Brian Fitzgerald and John Gilchrist eds., 2015).

35 See AP, Pirate Party gains three seats in Iceland's parliament, CBS NEWS (Apr. 30, 2013, 12:16 PM), http://www.cbsnews.com/news/pirate-party-gains-three-seats-inicelands-parliament/, archived at https://perma.cc/R29V-MNRP.

${ }^{36}$ See Gurry supra note 26. See e.g., Miaoran Li, The Pirate Party and The Pirate Bay: How the Pirate Bay Influences Sweden And International Copyright Relations, 21 PACE INT'L L. REV. 281 (2009); see also Jonas Anderson, For the Good of the Net: The Pirate Bay as a Strategic Sovereign, 10 CULTURE MACHINE 64 (2009); see also NERI LUCA, LA BAiA DEI PiRATI: AsSAlto Al COPYRIGHT (Cooper Editore 2009).
} 


Richmond Journal of Law \& Technology $\quad$ Volume XXIII, Issue 2

should return to its roots, because as it is now, it may cause more harm than good-proving that the sentiment is widespread. ${ }^{37} \mathrm{~A}$ recent Report from the Australian Government Productivity Commission widely criticized the present "copy(not)right" model, pointing at a number of very critical issues:

...Australia's copyright arrangements are weighed too heavily in favour of copyright owners, to the detriment of the long-term interests of both consumers and intermediate users. Unlike other IP rights, copyright makes no attempt to target those works where 'free riding' by users would undermine the incentives to create. Instead, copyright is overly broad; provides the same levels of protection to commercial and non-commercial works; and protects works with very low levels of creative input, works that are no longer being supplied to the market, and works where ownership can no longer be identified. ${ }^{38}$

[11] Therefore, copyright law has fallen into a deep crisis of acceptance with respect to both users and creators. ${ }^{39}$ Especially with new

${ }^{37}$ See Copyright and Wrong: Why the Rules on Copyright need to Return to Their Roots, THE ECONOMIST (Apr. 8, 2010),

http://www.economist.com/displayStory.cfm?story_id=15868004, archived at . https://perma.cc/N5JU-YU4U.

${ }^{38}$ Austl. Productivity Commission, InTELl. Prop. ArRangements, DRFT. ReP. 1617 (2016), https://assets.documentcloud.org/documents/2819862/Intellectual-PropertyDraft.pdf, archived at https://perma.cc/4WFS-4GTU.

${ }^{39}$ See generally, JESSICA SILBEY, The Eureka Myth: Creators, Innovators, and Everyday Intellectual Property (Stan. U. Press 2015) (noting that, after collecting interview-based empirical data, suggesting that creators - and even businesses - need intellectual property and exclusivity overstates, if not misstates, the facts and explaining how this misunderstanding about creativity sustains a flawed copyright system); see also Jessica Litman, Real Copyright Reform, 96 IowA L. REv. 1, 3-5, 31-32 (2010) (noting that "the deterioration in public support for copyright is the gravest of the dangers facing the copyright law in a digital era...[c]opyright stakeholders have let copyright law's legitimacy crumble..."); see also JOHN TEHRANIAN, Infringement Nation: Copyright 2.0 and You xvi-xxi (Oxford U. Press 2011); see also Brett Lunceford \&cohenle Shane Lunceford, The Irrelevance Of Copyright In The Public Mind, 7 Nw. J. TECH. \& INTELL. PROP. 33 (2008). 


\begin{tabular}{ll}
\hline Richmond Journal of Law \& Technology & Volume XXIII, Issue 2 \\
\hline
\end{tabular}

generations, ${ }^{40}$ copyright tends to become irrelevant in the public mind, if not altogether opposed. ${ }^{41}$ Sharing a common opinion, David Lange noted that the over-expansion of copyright entitlements lies at the backbone of their crisis in public acceptance:

...Raymond Nimmer has said that copyright cannot survive unless it is accorded widespread acquiescence by the citizenry. I think his insight is acutely perceptive and absolutely correct, for a reason that I also understand him to endorse: Never before has copyright so directly confronted individuals in their private lives. Copyright is omnipresent. But what has to be understood as well is that copyright is also correspondingly over-extended. ${ }^{42}$

[12] Technological and cultural change played a central role in lowering the acceptance of an over-expansive copyright paradigm. Ubiquitous technology, cost minimization, and the emergence of fan authorship radically affect the traditional market failure that copyright is supposed to cure, both at the creation and distribution levels. The distributive power of the Internet instituted new economics of distribution for digital content. ${ }^{43}$ Distribution and reproduction marginal costs being close to zero potentially eliminates, or at least strongly reduces, the need for third-party investment. In The Creative Destruction of Copyrights, Raymond $\mathrm{Ku}$ wonders whether a copyright monopoly at close to zero

\footnotetext{
${ }^{40}$ See e.g., Music Downloading, File-Sharing and Copyright, Pew Res. CTR.: INTERnET \& AM. LIFE PROJECT, http://pewinternet.org/t2003/07/31/music-downloading-filesharing-and-copyright/, archived at https://perma.cc/X3GP-DL25.

${ }^{41}$ See id.

${ }^{42}$ David Lange, Reimagining The Public Domain, 66 LAW \& CONTEMP. ProBs. 471 (2003).

${ }^{43}$ See Sacha Wunsch-Vincent, The Economics of Copyright and the Internet: Moving to an Empirical Assessment Relevant in the Digital Age, (World Intell. Prop. Org., Economic Research Working Paper No. 9, 2013) at 2, http://www.wipo.int/edocs/pubdocs/en/wipo_pub_econstat_wp_9.pdf, archived at https://perma.cc/QN3C-A7XL.
} 


Richmond Journal of Law \& Technology $\quad$ Volume XXIII, Issue 2

marginal cost is still a sustainable option. ${ }^{44} \mathrm{Ku}$ concludes that, absent the need for encouraging content distribution, the artificial scarcity and exclusive rights created by copyright cannot find any other social reason for existence. ${ }^{45}$ When distributors' rights are unbundled from creators' rights, society can no longer support the protection of distributors' rights. ${ }^{46}$ Under these circumstances, copyright would serve no other social purpose than transferring wealth from the public to distributors. ${ }^{47}$ Therefore, in $\mathrm{Ku}$ 's view, copyright in the digital environment is a meaningless burden for society and should be eliminated. ${ }^{48}$ As radical as Ku's position may be, if technological innovation led to a substantial reduction of the production, reproduction, and distribution costs of cultural artefacts, a case could be made in sharp contrast with any position asserting the expansion of the copyright monopoly.

[13] Reproduction and distribution cost minimization also affected the traditional discourse regarding incentive to create. ${ }^{49}$ Reductions in the production and distribution costs of original expressive works encourages non-professional authors to create. ${ }^{50}$ Therefore, the number of authors, for

\footnotetext{
${ }^{44}$ See Ku supra note 1, at 300-305; see also Raymond S. R. Ku, Consumers and Creative Destruction: Fair Use Beyond Market Failure, 18 Berkeley TeCH. L. J. 539 (2003); see also Paul Ganley, The Internet, Creativity and Copyright Incentives, $10 \mathrm{~J}$. InTELL. PROP. RTS. 188 (2005); see also John F. Duffy, The Marginal Cost Controversy In Intellectual Property, 71 U. CHI. L. REV. 37 (2004).

${ }^{45}$ See $\mathrm{Ku}$, Consumers and Creative Destruction: Fair Use Beyond Market Failure, supra note 44 at 539 .

${ }^{46}$ See id. at 566.

${ }^{47}$ See id.

${ }^{48}$ See $\mathrm{Ku}$, supra note 1, at 304-305.

${ }^{49}$ See Ku, Consumers and Creative Destruction: Fair Use Beyond Market Failure, supra note 44 at 539.

${ }^{50}$ See Tom W. Bell, The Specter of Copyism v. Blockheaded Authors: How UserGenerated Content Affects Copyright Policy, 10 VAND. J. ENT. \& TECH. L. 841, 853 (2008).
} 
whom the lucre of copyright proves a necessary stimulus, should drop. Additionally, low marginal costs empower few authors to reach a broader audience. ${ }^{51}$ If decentralized and unprofessional authors increasingly satisfy the market demand-because non-monetary incentives stimulate creation-a copyright monopoly will eventually prove superfluous, at least for these works. ${ }^{52}$ In respect to creative works provided by decentralized and unprofessional authors, the burdens of a copyright monopoly will exceed its benefits. ${ }^{53}$

[14] This crisis propelled a cultural copyright resistance movement. Neelie Kroes stressed that copyright fundamentalism has prejudiced our capacity to explore new models in the digital age:

So new ideas which could benefit artists are killed before they can show their merit, dead on arrival. This needs to change....So that's my answer: it's not all about copyright. It is certainly important, but we need to stop obsessing about that. The life of an artist is tough: the crisis has made it tougher. Let's get back to basics, and deliver a system of recognition and reward that puts artists and creators at its heart. $^{54}$

[15] The digital opportunity led many to challenge the obsolescence of the traditional copyright monopoly, seeking more radical reform. In 1994, John Perry Barlow's manifesto laid out the necessity of re-thinking digitized intellectual property and radically noted that: "[i]n the absence of

\footnotetext{
${ }^{51}$ See Wunsch-Vincent, supra note 43.

${ }^{52}$ See Bell, supra note 50, at 844.

${ }^{53}$ See id. at 855 .

${ }^{54}$ Neelie Kroes, Vice President, Eur. Comm'n, Speech at the Forum d'Avigon, Who Feeds the Artist? (Nov. 19, 2011) (transcript available at $\mathrm{http}: / /$ europa.eu/rapid/pressReleasesAction.do?reference=SPEECH\%2F11\%2F777), archived at https://perma.cc/QMV4-U24H.
} 


\begin{tabular}{ll}
\hline Richmond Journal of Law \& Technology & Volume XXIII, Issue 2 \\
\hline
\end{tabular}

the old containers, almost everything we think we know about intellectual property is wrong". 55 Nicholas Negroponte reinforced Barlow's point by stating that "[c]opyright law is totally out of date...[i]t is a Gutenberg artifact...[s]ince it is a reactive process, it will have to break down completely before it is corrected." that archaic copyright laws "obstruct[] innovation and economic growth[.]" ${ }^{, 57}$ In a message delivered to the G20 leaders, the President of Russia, Dimity Medvedev, pointed out that "[t]he old principles of intellectual property protection established in a completely different technological context do not work any longer in an emerging environment, and, therefore, new conceptual arrangements are required for international regulation of intellectual activities on the Internet."

[16] Many highlighted the necessity of re-shaping present copyright laws $^{59}$ or abolishing them altogether. ${ }^{60}$ In particular, a growing copyright

${ }^{55}$ John Perry Barlow, Selling Wine Without Bottles: The Economy of Mind on the Global Net, WIRED (Mar. 1, 1994), yin.arts.uci.edu/ studio/readings//barlow-wine.html, archived at https://perma.cc/FL5M-NBKF.

${ }^{56}$ Nicholas Negroponte, Being Digital 58 (First Vintage Books ed. 1996).

${ }^{57}$ Ian Hargreaves, Digital Opportunity: A Review of Intellectual Property and Growth 1 (2011).

${ }^{58}$ Dmitry Medvedev, President of Russ., Message to the G20 Leaders (Nov. 3, 2011) (transcript available at http://eng.kremlin.ru/news/3018), archived at . https://perma.cc/P9TL-7LGL.

${ }^{59}$ See, e.g., Pamela Samuelson, The Copyright Principles Project: Directions for Reform, 25 Berkeley TECH. L. J. 1175, 1178-79 (2010); see also William Patry, How to Fix Copyright (Oxford U. Press 2012); see also Diane Zimmerman, Finding New Paths through the Internet, Content and Copyright, 12 TUL. J. TECH. \& INTELL. PROP. 145, 145 (2009); see also Hannibal Travis, Opting Out of the Internet in the United States and the European Union: Copyright, Safe Harbors, and International Law, 84 NotRE DAME L. REV. 331, 335 (2008); see also Guy Pessach, Reciprocal Share-Alike Exemptions in Copyright Law, 30 CARDOZO L. REV. 1245, 1247 (2008); see also Jessica Litman, Sharing and Stealing, 27 HASTINGS COMM. \& ENT. L. J. 1, 2 (2004); see also Mark Lemley \& R. Anthony Reese, Reducing Digital Copyright Infringement Without Restricting Innovation, 56 STAN. L. REV. 1345, 1349-50 (2004); see also William Landes \& Richard Posner, Indefinitely Renewable Copyright, 70 U. CHI. L. REV. 471, 471 (2003). 


Richmond Journal of Law \& Technology $\quad$ Volume XXIII, Issue 2

"abolitionism" emerged online in response to a worrying tendency to criminalize the younger generation and new models of online digital creativity, such as mash-up, fanfiction, or machinima. ${ }^{61}$ The Committee on Intellectual Property Rights and the Emerging Information Infrastructure considered the notion that copying might not be an appropriate mechanism for achieving the goals of copyright in the digital age. ${ }^{62}$ Among the

${ }^{60}$ See, e.g., Stephen Breyer, The Uneasy Case for Copyright: A Study of Copyright in Books, Photocopies, and Computer Programs, 84 HARV. L. REV. 281, 282 (1970) (concluding "[i]t would be possible, for instance, to do without copyright, relying upon authors, publishers, and buyers to work out arrangements among themselves that would provide books' creators with enough money to produce them."); see also Jon M. Garon, Normative Copyright: A Conceptual Framework for Copyright Philosophy and Ethics, 88 CORNELL L. REV. 1278, 1283 (2003) (noting "[u]nless there is a valid conceptual basis for copyright laws, there can be no fundamental immorality in refusing to be bound by them."); see also Michele Boldrin and David Levine, Against Intellectual Monopoly (Cambridge U. Press 2008) (disputing the utility of intellectual property altogether); see also Martin Skladany, Alienation by Copyright: Abolishing Copyright to Spur Individual Creativity, 55 J. COPYRIGHT SOC'Y U.S.A. 361, 361 (2008); see also Joost Smiers and Marieke van Schijndel, Imagine There Is No Copyright and No Cultural Conglomerates Too (Inst. of Network Cultures 2009); see also Joost Smiers, Art Without Copyright: A Proposal for Alternative Regulation, in FREEDOM OF CULTURE: Regulation and Privatization of INTELlectual Property AND PUBliC SPaCe 2229 (Jorinde Seijdel trans., NAi Publishers 2007); see also Joost Smiers and Marieke Van Schijndel, Imagining a World Without Copyright: The Market and Temporary Protection, a Better Alternative for Artists and Public Domain, in COPYRIGHT AND OTHER FAIRY TALES: HANS CHRISTIAN ANDERSEN AND THE COMMODIFICATION OF CREATIVITY 129 (Helle Porsdam ed., Edward Elgar Publ'g Ltd. 2006); see also Frank Thadeusz, No Copyright Law: The Real Reason for Germany's Industrial Expansion?, SPIEGEL ONLINE (Aug. 18, 2010), http://www.spiegel.de/international/zeitgeist/0,1518,710976,00.html, archived at https://perma.cc/BPQ8-TG69 (providing a historical and empirical argument against copyright). Cf. Lior Zemer, The Conceptual Game in Copyright, 28 HASTINGS COMM. \& ENT L. J. 409, 409 (2006).

${ }^{61}$ See, e.g., Lawrence Lessig, Laws that Choke Creativity, TED (2007) (transcript available at

https://www.ted.com/talks/larry_lessig_says_the_law_is_strangling_creativity/transcript? language $=\mathrm{en}$ ), archived at $\mathrm{https} / / /$ perma.cc/9EFZ-GAX9.

${ }^{62}$ See Nat'1 Res. Council, Executive Summary, The Digital Dilemma: Intellectual Property in the Information Age, 62 OHIO ST. L. J. 951 (2001), http://moritzlaw.osu.edu/students/groups/oslj/files/2012/03/62.2.nrc_.pdf, archived at https://perma.cc/484D-RWU9. 
Richmond Journal of Law \& Technology $\quad$ Volume XXIII, Issue 2

inadequacies, the Committee highlights that "in the digital world copying is such an essential action, so bound up with the way computers work, that control of copying provides, in the view of some, unexpectedly broad powers, considerably beyond those intended by the copyright law."63 Sharing is essential to emerging digital culture. Young generations digitize, share, rip, mix, burn, and share again as a basic form of human interaction. Increasingly, many social forces maintain that full recognition of a non-commercial right to share creative works should be the goal of modern policies for digital creativity. At the same time, criminalization of Internet users by cultural conglomerates is a source of social tension. ${ }^{64} \mathrm{At}$ the WIPO Global Meeting on Emerging Copyright Licensing ModalitiesFacilitating Access to Culture in the Digital Age, Lessig called for an overhaul of the copyright system, which would "never work on the internet" and "[i]t'll either cause people to stop creating or it'll cause a revolution." ${ }^{65}$

[17] Resistance to copyright lies at the crossroad between academic investigation, civic involvement, and political activity. As Michael Strangelove argued in the Empire of Mind, the Internet set in motion an anti-capitalistic movement resistant to authoritarian forms of consumer capitalism and globalization. ${ }^{66}$ This movement is "resisting the resistance" to change, resisting copyright, seeking access to knowledge and promoting

\footnotetext{
${ }^{63}$ National Research BoARd, The Digital Dilemma: Intellectual Property in THE INFORMATION AGE 140 (National Academy Press, 2000).

${ }^{64}$ See COPYRIGHT POLICY, CREATIVITY, AND INNOVATION IN THE DIGITAL ECONOMY, USPTO (July 2013), https://www.uspto.gov/sites/default/files/news/publications/copyrightgreenpaper.pdf, archived at https://perma.cc/K3B8-33GG (demonstrating how lawmakers have struggled for years trying to strike a balance).

${ }^{65}$ See Larry Lessig, Speech at the WIPO Global Meeting on Emerging Copyright Licensing Modalities -Facilitating Access to Culture in the Digital Age, Geneva, Switzerland (November 4, 2010), available at http://www.wipo.int/meetings/en/2010/wipo_cr_lic_ge_10/program.html, archived at https://perma.cc/K7C2-FXLU.

${ }^{66}$ See Michael Strangelove, The Empire of Mind: Digital Piracy and the AntiCAPITAlist Movement (University of Toronto Press 2005).
} 


Richmond Journal of Law \& Technology $\quad$ Volume XXIII, Issue 2

the public domain. Creative Commons (CC), the Free Software Foundation, and the Open Source movement, ${ }^{67}$ propelled the diffusion of viable market alternatives to traditional copyright management. The "power of open," as Catherine Casserly and Joi Ito have termed creative commons, has spread quickly with more than four hundred million CClicensed works available on the Internet. ${ }^{68}$ Again, mostly driven by scholarly efforts, projects like the Access to Knowledge (A2K) Movement, the Open Access Publishing Movement, and the Public Domain Project lead the resistance to copyright over-expansion by seeking to re-define the hierarchy of priorities embedded in the traditional politics of intellectual property. ${ }^{69}$ Meanwhile, proposals for reform tackled the uneasy coexistence between copyright, digitization, and the networked information economy. ${ }^{70}$ I will discuss these proposals first and later discuss the social movements resisting the resistance.

\section{A. Copyright Terms, Formalities and Registration Systems}

[18] As suggested by some scholars, a potential solution to the weaknesses of the current copyright regime is a setting in which published works are not copyrighted unless the authors comply with specific

${ }^{67}$ See, e.g., Moglen Eben, Freeing the Mind: Free Software and the Death of Proprietary Culture, June 29, 2003, available at http://emoglen.law.columbia.edu/publications/mainespeech.html, archived at https://perma.cc/44SB-9U3G; see also Moglen Eben, Anarchism Triumphant: Free Software and the Death of Copyright, June 28, 1999, available at $\mathrm{http} / / / \mathrm{emoglen} .1 \mathrm{aw} . \mathrm{columbia} . \mathrm{edu} /$ publications/anarchism.html, archived at https://perma.cc/Q93F-5LZW.

\footnotetext{
${ }^{68}$ See CATHerine CASSerly AND Joi Ito, The Power of Open (Creative Commons 2011), http://thepowerofopen.org, archived at https://perma.cc/WBD4-CDK4; see also Niva Elkin-Koren, Exploring Creative Commons: A Skeptical View of a Worthy Pursuit, in THE Future of THE PUblic DOMAIN: IDENTIFYING THE COMMONS IN INFORMATION LAW 325-345 (Lucie Guibault and P. Bernt Hugenholtz eds., Kluwer Law International 2006).

${ }^{69}$ See Giancarlo Frosio, Communia Final Report 50-60, (Communia 2011), http://communia-project.eu/final-report/defining-public-domain.html (last visited January 31, 2017).

${ }^{70}$ See, e.g., supra note 64 at iii.
} 


\begin{tabular}{ll}
\hline Richmond Journal of Law \& Technology & Volume XXIII, Issue 2 \\
\hline
\end{tabular}

formalities. These formalities should be very simple, cheap, and nondiscriminatory with respect to national versus foreign authors. ${ }^{71}$

[19] The international community was persuaded to abolish most discriminatory hurdles in the analog world; similarly, the digital era may provide opportunities for creativity in adapting formalities. ${ }^{72}$ The idea of a global online copyright registry for creative works is increasingly gaining momentum. ${ }^{73}$ A carefully crafted registration system may enrich the public domain, enhance access and reuse, and avoid transaction costs burdening digital creativity and digitization projects. ${ }^{74}$ Today, state-of-the-

${ }^{71}$ See, e.g., Lewis Hyde, How to Reform Copyright, THE CHRONICLE (October 9, 2011), $\mathrm{http} / / /$ chronicle.com/article/How-to-Reform-Copyright/129280, archived at https://perma.cc/U23A-CMJJ; see also Christopher Sprigman, Reform(aliz)ing Copyright, 57 STAN. L. REV. 485 (2004) (proposing an optional registration system that subjects unregistered works to a default license under which the use of the work would trigger only a modest statutory royalty liability); see also LAWRENCE LESSIG, FREE Culture: How Big Media Uses Technology and the Law to Lock Down Culture and Control Creativity 140 (Penguin 2004); see also LaWrence Lessig, The Future OF IDEAS: The FATE OF THE COMMONS IN A CONNECTED World (Vintage Books 2002); see also Lawrence Lessig, Recognizing the Fight We're In, Keynote Speech delivered at the Open Rights Group Conference, London, UK (March 24, 2012), at 36:40-38:28, available at $\mathrm{http} / / / \mathrm{vimeo} . \mathrm{com} / 39188615$, archived at https://perma.cc/7K5Q-DUJY (proposing the reintroduction of formalities at least to secure extensions of copyright, if legislators decide to introduce them).

${ }^{72}$ See Stef van Gompel, Formalities in the digital era: an obstacle or opportunity?, in Global Copyright: Three Hundred Years Since the Statute of ANNe, From 1709 TO CYBERSPACE 2-4 (Lionel Bently, Uma Suthersanen and Paul Torremans eds., Edward Elgar 2010) (arguing that the pre-digital objections against copyright formalities cannot be sustained in the digital era); see also Takeshi Hishinuma, The Scope of Formalities in International Copyright Law in a Digital Context, in GLOBAL COPYRIGHT: THREE HundRED YeARS SinCE THE STATUTE OF ANNE, FROM 1709 TO CyberSPACE 460-467 (Lionel Bently, Uma Suthersanen and Paul Torremans eds., Edward Elgar 2010).

${ }^{73}$ See Andrew Gowers, Gowers Review of InTELLECTUAL Property (HM Treasury, November 2006), at 6 , ([r]ecommendation $14 \mathrm{~b}$ endorses the establishment of a voluntary register of copyright), https://www.gov.uk/government/uploads/system/uploads/attachment_data/file/228849/01 18404830.pdf, archived at https://perma.cc/P755-ZSZZ.

${ }^{74}$ See $i d$. at 40. 
Richmond Journal of Law \& Technology $\quad$ Volume XXIII, Issue 2

art technology enables the creation of global digital repositories that ensure the integrity of digital works, render filings user-friendly and inexpensive, and enable searches on the status of any creative work. ${ }^{75}$ Registration could be a precondition for protection by providing the creators with full ownership rights, while, absent registration, the default level of protection would be limited to the moral right of attribution. Alternatively, if making global registration, rather than notice, a precondition for protection is considered too harsh a requirement, then registration might at least be required as a precondition of protection extensions.

[20] In particular, registries and data collection should ease the orphan works problem. $^{76}$ Measures to improve the provision of rights management information range from encouraging digital content metadata tagging, to promoting the use of CC-like licenses, and encouraging the voluntary registration of rights ownership information in specifically designed databases. ${ }^{77}$ Many projects aim at increasing the supply of rights management information to the public, merging unique sources of rights information, and establishing specific databases for orphan works. Notably, the EU mandated project ARROW (Accessible Registries of Rights Information and Orphan Works) includes national libraries,

\footnotetext{
${ }^{75}$ See Tanya Aplin, A Global Digital Register for the Preservation and Access to Cultural Heritage: Problems, Challenges and Possibilities, in COPYRIGHT AND Cultural Heritage: Preservation And Access to Works in a Digital World 3, at 23 (Estelle Derclaye (ed.), Edward Elgar 2010) (discussing copyright registers); see also Caroline Colin, Registers, Databases and Orphan Works, in COPYRIGHT AND CULTURAL HeritAGe: PRESERVATION AND ACCESS TO WORKS IN A DigitAl WORLD, supra, 28, at 29; see also Steven Hetcher, A Central Register of Copyrightable Works: a U.S. Perspective, in COPYRIGHT AND CUltural Heritage: Preservation AND ACCESS TO WORKS IN A DIGITAL WORLD, 156, at 158.

${ }^{76}$ See Orphan Works and Mass Digitization: A Report of the Register of Copyrights, UNITED STATES COPYRIGHT OFFICE at 66 (June 2015), https://www.copyright.gov/orphan/reports/orphan-works2015.pdf, archived at https://perma.cc/642S-N52A.

${ }^{77}$ See van Gompel, supra note 72, at 12-13 (noting that only voluntary supply of information would be compliant with the no-formalities prescription of the Berne Convention).
} 


\begin{tabular}{ll}
\hline Richmond Journal of Law \& Technology & Volume XXIII, Issue 2 \\
\hline
\end{tabular}

publishers, writers' organizations and collective management organizations. It aspires to find ways of identifying rights holders, determining and clearing rights, and possibly confirming the public domain status of a work. $^{78}$

[21] Marco Ricolfi's Copyright 2.0 proposal is a specific articulation of an alternative copyright default rule, coupled with the implementation of a formality and registration system. ${ }^{79}$ Similar proposals have been made by other scholars, such as Lessig. ${ }^{80}$ In Ricolfi's Copyright 2.0, traditional copyright, or Copyright 1.0 , is still available. In order to be enjoyed, Copyright 1.0 has to be claimed by the creator at the onset, for example by inserting a copyright notice before the first publication of a work. ${ }^{81}$ In certain conditions, the Copyright 1.0 notice could also be added after the first publication, possibly during a short grace period. ${ }^{82}$ The Copyright 1.0

\footnotetext{
${ }^{78}$ See ACCESSIBLE REGISTRIES OF RIGHTS INFORMATION AND ORPHAN WORKS [ARROW], http://www.arrow-net.eu, archived at https://perma.cc/RE3M-NS7K (creating registries of rights information and orphan works); see also Barbara Stratton, Seeking New Landscapes: a Rights Clearance Study in the Context of Mass Digitization of 140 Books Published between 1870 and 2010, at 5, 35-36 (British Library 2011), https:/www.arrow-net.eu/sites/default/files/Seeking\%20New\%20Landscapes.pdf, archived at https://perma.cc/WR5D-6SLR, (showing that in contrast to the average four hours per book to undertake a diligent search, "the use of the ARROW system took less than 5 minutes per tile to upload the catalogue records and check the results.").

${ }^{79}$ See Marco Ricolfi, Copyright Policies for Digital Libraries in the Context of the i2010 Strategy, at 2, 6 (July 1, 2008), http:/www.communiaproject.eu/communiafiles/conf2008p_Copyright_Policy_for_digital_libraries_in_the_con text_of_the_i2010_strategy.pdf, archived at https://perma.cc/4439-9JY9 (paper presented at the 1st COMMŪNIA Conference); see also Marco Ricolfi, Making Copyright Fit for the Digital Agenda, 5-6 (Feb. 25, 2011), available at http://nexa.polito.it/nexafiles/Making\%20Copyright $\% 20$ Fit $\% 20$ for $\% 20$ the $\% 20$ Digital $\% 2$ 0Agenda.pdf, archived at https://perma.cc/X4UZ-QCMJ.

${ }^{80}$ See Lawrence Lessig, Remix: Making Art and Commerce Thrive in the Hybrid Economy 253-255 (Bloomsbury 2008) (proposing different routes for professional, remix and amateur authors, registries, and the re-introduction of formalities and an opt-in system).

${ }^{81}$ See Ricolfi, Making Copyright Fit for the Digital Agenda, supra note 79 at 6.

${ }^{82}$ See id.
} 
protection given by the original notice is deemed withdrawn after a specified short period of time, unless an extension period is formally requested through an Internet based renewal and registration procedure, whose registration data would be accessible online. ${ }^{83}$ If no notice is given, Copyright 2.0 applies, and giving creators mainly one right, the right to attribution. ${ }^{84}$

\section{B. Mandatory Exceptions and Diligent Search for Orphan Works and UGC}

[22] Nellie Kroes warns against the welfare loss of the immense cultural riches unveiled by digitization, nevertheless locked behind the intricacies of an outdated copyright model.$^{85}$

Think of the treasures that are kept from the public because we can't identify the right-holders of certain works of art. These "orphan works" are stuck in the digital darkness when they could be on digital display for future generations. It is time for this dysfunction to end. ${ }^{86}$

[23] Institutional proposals in both Europe and the United States advocate the implementation of a diligent search system as a defense to copyright infringement. A report from the United States Copyright Office recommended that Congress enact legislation to limit liability for copyright infringement if the alleged infringer performed "a reasonably

\footnotetext{
${ }^{83}$ See id.

${ }^{84}$ See id.

${ }^{85}$ Neelie Kroes, Vice-President of the European Commission responsible for the Digital Agenda, Speech at Business for New Europe event: Ending Fragmentation of the Digital Single Market (Feb. 7, 2010) (transcript available at http://europa.eu/rapid/pressrelease_SPEECH-11-70_en.htm?locale=en, archived at https://perma.cc/WJM6-QJMT), at 2 .

${ }^{86} I d$.
} 


Richmond Journal of Law \& Technology $\quad$ Volume XXIII, Issue 2

diligent search" before any use. ${ }^{87}$ Additionally, the Copyright Office laid down several suggestions to promote privately-operated registries as a more efficient arrangement than government-operated registries. The Copyright Office's recommendations were included in the Orphan Works Act of 2006, and again in the Orphan Works Act of 2008. ${ }^{88}$ So far, neither bill has been adopted into law. The High Level Expert Group on the European Digital Libraries Initiative made similar recommendations:

Member States are encouraged to establish a mechanism to enable the use of such works for non-commercial and commercial purposes, against agreed terms and remuneration, when applicable, if diligent search in the country of origin prior to the use of the works has been performed in trying to identify the work and/or locate the rightholders...The mechanisms in the Member States need to fulfill prescribed criteria... the solution should be applicable to all kinds of works; a bona fide/good faith user needs to conduct a diligent search prior to the use of the work in the country of origin; best practices or guidelines specific to particular categories of works can be devised by stakeholders in different fields. ${ }^{89}$

[24] The system should be based on reciprocity so that Member States will recognize solutions in other Member States that fulfill the prescribed criteria. As a result, materials that are lawful to use in one Member State would also be lawful to use in another. Partially endorsing these

\footnotetext{
${ }^{87}$ See U.S. COPYRIGHT OfFICE, REP. OF THE REG. OF COPYRIGHTS: REP. ON ORPHAN WORKS 95 (Jan. 2006).

${ }^{88}$ See Christian L. Castle \& Amy E. Mitchell, Unhand That Orphan: Evolving Orphan Works Solutions Require New Analysis, 27 EnT. \& SpORTS LAW. 1 (Spring 2009).

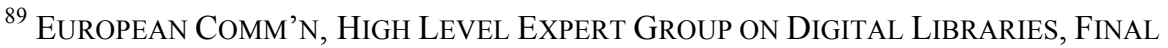
REPORT: DIGITAL LIBRARIES: RECOMMENDATIONS AND CHALLENGES FOR THE FUTURE 4 (Dec. 2009) (i2010 European Digital Libraries Initiative).
} 


Richmond Journal of Law \& Technology $\quad$ Volume XXIII, Issue 2

principles, a Directive on certain permitted uses of orphan works has been recently enacted by the European Commission. ${ }^{90}$

[25] In Europe, the most comprehensive proposal for an orphan works' mandatory exception is outlined in a paper for the Gowers Review by the British Screen Advisory Committee (BSAC). ${ }^{91}$ This proposal sets up a compensatory liability regime. ${ }^{92}$ First, to trigger the exception, a person is required to have made 'best endeavours' to locate the copyright owner of a work. ${ }^{93}$ 'Best endeavours' would be judged against the particular circumstances of each case. The work must also be marked as used under the exception to alert any potential rights owners. ${ }^{94}$ If a rights owner emerges, he is entitled to claim a 'reasonable royalty' agreed upon by negotiation, rather than sue for infringement. If the parties cannot reach agreement, a third party steps in to establish the royalty amount. The terms of use of the formerly-orphan work would need to be negotiated between the user and the rights owner, according to the traditional copyright rules. However, users should be allowed to continue using the work that has been integrated or transformed into a derivative work, contingent upon payment of a reasonable royalty and sufficient attribution. Slightly modified versions of the U.S. and European model have been also investigated. For example, Canada established a compulsory licensing system based on diligent searches to use orphan works. ${ }^{95}$

\footnotetext{
${ }^{90}$ See Council Directive 2012/28/EU, of the European Parliament and of the Council of 25 October 2012 on Certain Permitted Uses of Orphan Works, 2012 O.J. (L 299/5), 3 [hereinafter Orphan Works Directive].

${ }^{91}$ BRITISH SCREEN ADVISORY COUNCIL, COPYRIGHT AND ORPHAN WORKS 3 (Aug. 31, 2006), http://www.bsac.uk.com/wpcontent/uploads/2016/02/copyright_orphan_works_paper_prepared_for_gowers_2006.p df, archived at https://perma.cc/V9TA-G6ML (paper prepared for the Gowers Review).

${ }^{92}$ See id. at 16.

${ }^{93} I d$. at 25.

${ }^{94}$ See id. at 30.

${ }^{95}$ See Copyright Act, R.S.C. 1985, c C-42, art. 77 (Can). Under the Canadian system, users can apply to an administrative body to obtain a license to use orphan works. In order to obtain the license the applicant must prove that they have conducted a serious
} 


Richmond Journal of Law \& Technology $\quad$ Volume XXIII, Issue 2

[26] In addition to orphan works, user-generated content (UGC) is another massive phenomenon that struggles with present copyright law. Mandatory exceptions have been claimed as a solution for user-generated content, together with the use of informal copyright practices. ${ }^{96}$ Proposals have been made for introducing an exception for transformative use in user-generated works. ${ }^{97}$ Both specific and general exception clauses have been under discussion. ${ }^{98}$ Canada introduced a specific exception to this effect, allowing the use of a protected work - which has been published or otherwise made available to the public - in the creation of a new work, if the use is done solely for non-commercial purposes and does not have substantial adverse effects on the potential market for the original work. ${ }^{99}$

search for the rightsholder. If the Canadian Copyright Board is satisfied that, despite the search, the rightsholders cannot be identified, it issues the applicant a non-exclusive license to use the work. The license will shield the license holder from any liability for infringement. However, the license is limited to Canada. see id.

${ }^{96}$ See Steven A. Hetcher, Using Social Norms to Regulate Fan Fiction and Remix Culture, 157 U. PA. L. REv. 1869, 1880 (2009); see also Edward Lee, Warming Up To User-Generated Content, 2008 U. ILL. L. REV. 1459, 1461 (2008) (noting that "informal copyright practices - i.e., practices that are not authorized by formal copyright licenses but whose legality falls within a gray area of copyright law — effectively serve as important gap fillers in our copyright system").

${ }^{97}$ See e.g., Daniel Gervais, The Tangled Web of UGC: Making Copyright Sense of UserGenerated Content, 11 VAND. J. ENT. \& TECH. L. 841, 869-70 (2009); see also Debora Halbert, Mass Culture and the Culture of the Masses: A Manifesto for User-Generated Rights, 11 VAND. J. ENT. \& TECH. L. 921, 958 (2009); see also Mary W. S. Wong, "Transformative" User-Generated Content in Copyright Law: Infringing Derivative Works or Fair Use?, 11 VAND. J. ENT. \& TECH. L. 1075, 1110 (2009).

${ }^{98}$ See, e.g., Peter K. Yu, Can the Canadian UGC Exception Be Transplanted Abroad?, 26 INTELL. PROP. J. 176, 176-79 (2014) (discussing also a Hong Kong proposal for a UGC exception); see also Warren B. Chik, Paying it Forward: The Case for a Specific Statutory Limitation on Exclusive Rights for User-Generated Content Under Copyright Law, 11 J. Marshall Rev. Intell. Prop. L. 240, 270 (2011).

${ }^{99}$ See An Act to Amend the Copyright Act, 2010, Bill C-32, art. 22 (Can.), http://www.parl.gc.ca/HousePublications/Publication.aspx?Docid=4580265\&file=4, archived at https://perma.cc/LJ8N-9WPW (introducing an exception for non-commercial UGC). 


\begin{tabular}{ll}
\hline Richmond Journal of Law \& Technology & Volume XXIII, Issue 2 \\
\hline
\end{tabular}

Likewise, European institutions and stakeholders have recently discussed specific exceptions for UGC, after sidelining proposals for micro-licensing arrangements. ${ }^{100}$ In a narrower context, the U.S. Copyright Office rulemaking on the Digital Millennium Copyright Act (DMCA) anticircumvention provisions recently introduced an exception for the use of movie clips for transformative, non-commercial works, bringing a breath of fresh air to the world of 'vidding. ${ }^{101}$ Also, general fair use exception clauses, if properly construed, may prove effective to give UGC creators some breathing space. ${ }^{102}$ In particular, recent U.S. case law protects UGC creators from bogus DMCA takedown notices in cases of blatant misrepresentation of fair use defences by copyright holders. In Lenz $v$. Universal Music, the 9th Circuit ruled that "the statute requires copyright holders to consider fair use before sending takedown notification." ${ }^{103}$ The Court also recognized the possible applicability of section 512(f) of the DMCA that allows for the recognition of damages in case of proven badfaith, which would occur if the copyright holder did not consider fair use

\footnotetext{
${ }^{100}$ See Eur. COMmission, ReP. ON THE Responses to the Public Consultation ON THE REVIEW OF THE EU COPYRIGHT RULES 68 (July 2014), http://ec.europa.eu/internal_market/consultations/2013/copyrightrules/docs/contributions/consultation-report_en.pdf, archived at https://perma.cc/D3FGYMBD (noting that respondents often favor a legislative intervention, which could be done "by making relevant existing exceptions (parody, quotation and incidental use and private copying are mentioned) mandatory across all Member States or by introducing a new exception to cover transformative uses"); see also EUR. COMMISSION, COMMISSION COMM. ON CONTENT IN THE Digital Single MKT. 3-4 (2011), http://eurlex.europa.eu/legal-content/EN/ALL/?uri=CELEX:52012DC0789, archived at https://perma.cc/KW6C-6CKJ (proposing licensing arrangements).

${ }^{101}$ See U.S. COPYRIGHT OfFice, RulEMAKING ON EXEMPTIONS FROM Prohibition ON Circumvention of TeChNOlogical Measures that Control AcCess to COPYRIGHTED WORKS (Jul. 26, 2010), http://www.copyright.gov/1201/2010, archived at https://perma.cc/83D6-7QTM.

${ }^{102}$ See Mariam Awan, The User-Generated Content Exception: Moving Away From a Non-Commercial Requirement (Nov. 11, 2015), at 6, 8-9, http://www.iposgoode.ca/wpcontent/uploads/2015/11/Mariam-Awan-The-user-generated-content-exception.pdf, archived at $\mathrm{https}: / /$ perma.cc/FW84-UANW.

${ }^{103}$ Lenz v. Universal Music Corp., 801 F.3d 1126, $1129\left(9^{\text {th }}\right.$ Cir. 2015).
} 
or paid "lip service to the consideration of fair use by claiming it formed a good faith belief when there is evidence to the contrary." "104

\section{Extended and Mandatory Collective Management}

[27] Extended Collective Licenses (ECL) are applied in various regions in Denmark, Finland, Norway, Sweden, and Iceland. ${ }^{105}$ The ECL arrangement has become a tempting policy option in several jurisdictions, both to tackle the orphan works problem, and the larger issue of file sharing in digital networks. ${ }^{106}$ In particular, a recent draft directive would

\footnotetext{
${ }^{104} I d$. at $1134-35$ (noting also that there's no liability under $\S 512$ (f), "[i]f, however, a copyright holder forms a subjective good faith belief the allegedly infringing material does not constitute fair use").

105 See, e.g., Zijian Zhang, Transplantation of an Extended Collective Licensing System Lessons from Denmark, 47 INT'L REV. InTELL. PROP. \& COMPETITION L. 640, 641-42 (2016).

${ }^{106}$ See European COMM’n, High LEVEl EXPERT Group-COPYRIGHT SubGroup, REPORT ON DIGITAL PRESERVATION, ORPHAN WORKS AND OUT-OF-PRINT WORKS: SELECTED IMPLEMENTATION ISSUES 5 (Apr. 18, 2008) (i2010 European Digital Libraries Initiative),

http://ec.europa.eu/information_society/newsroom/cf/itemlongdetail.cfm?item_id=\%203 366, archived at https://perma.cc/M3EA-VCGG (identifying ECL as a possible solution to the orphan works' problem); see also Jia Wang, Should China Adopt an Extended Licensing System to Facilitate Collective Copyright Administration: Preliminary Thoughts, 32 EUR. INTELL. Prop. REV. 283, (2010); see also Marco Ciurcina, et al., Creatività Remunerata, Conoscenza Liberata: File Sharing e Licenze Collettive Estese [Remunerating Creativity, Freeing Knowledge: File-Sharing and Extended Collective Licences], NEXA CTR. FOR INTERNET \& SOC'Y, at 8 (It.) (Mar. 15, 2009), http://nexa.polito.it/nexafiles/NEXACenter-ExtendedCollectiveLicenses-EnglishVersionJune2009.pdf, archived at https://perma.cc/KB75-N8VY (highlighting the positive externalities of the adoption an extended collective licensing scheme as the most appropriate tool to be used by a European Member State to legitimize the file-sharing of copyrighted content); see also Johan Axhamn \& Lucie Guibault, Cross-border Extended Collective Licensing: A Solution to Online Dissemination of Europe's Cultural Heritage?, INSTITUUT VOOR INFORMATIERECHT , at 4 (Neth.)(Aug. 2011), http://www.ivir.nl/publicaties/download/292, archived at https://perma.cc/D5VQ-K2JF.
} 


\begin{tabular}{ll}
\hline Richmond Journal of Law \& Technology & Volume XXIII, Issue 2 \\
\hline
\end{tabular}

apply this collective management mechanism to the use of out-ofcommerce works by cultural heritage institutions. ${ }^{107}$

[28] The system combines the voluntary transfer of rights from rights holders to a collective society with the legal extension of the collective agreement to third parties who are not members of the collective society. However, to be extended to third parties of the same category, the collective society must represent a substantial number of rights holders. ${ }^{108}$ In any event, the legislation in Nordic countries provides the rights holders with the option of claiming individual remuneration or opting out from the system. ${ }^{109}$ Therefore, with the exception of the rights holders who opted out, the extended collective license automatically applies to all domestic and foreign rights owners, unknown or untraceable rights holders, and deceased rights holders, even where estates have yet to be arranged. With an extended collective licensing scheme in place, a user may obtain a license to use all the works included in a certain category, with the exception of the opted out works. Re-users of existing works should have no legal concerns all orphan works will be covered by the license, opted out works instantly cease to be orphan. If ECL is applied to legitimize file-sharing, collective management bodies will negotiate the license with users' associations or internet service providers (ISPs). In exchange for the right of reproductioning and making available content online, rights holders will be remunerated by the proceedings collected through the extended collective license. A related proposal would place the right to make available to the public under mandatory collective management. ${ }^{110}$

\footnotetext{
${ }^{107}$ See Commission Proposal for a Directive of the European Parliament and of the Council on Copyright in the Digital Single Market, at 26, COM (2016) 593 final (Sept. 14, 2016) [hereinafter DSM Directive Proposal].

${ }^{108}$ See id.

${ }^{109}$ See id. at 5,30 .

${ }^{110}$ See Silke v. Lewinski, Mandatory Collective Administration of Exclusive Rights - A Case Study on its Compatibility with International and EC Copyright Law, E-COPYRIGHT BULLETIN (UNESCO), Jan.-Mar. 2004 at 2 (discussing a proposed amendment in the Hungarian Copyright Act); see also Carine Bernault \& Audrey Lebois, Peer-to-Peer File Sharing and Literary and Artistic Property: A Feasibility Study Regarding a System of Compensation for the Exchange of Works via the Internet (June 2005) (discussing the
} 


Richmond Journal of Law \& Technology $\quad$ Volume XXIII, Issue 2

According to this proposal, to enjoy the economic rights attached to the right of making available to the public, rights holders would be obligated to use collective management. As a consequence, the ISPs would pay a lump-sum fee or levy to the collective societies in exchange for the authorization to download and make the collective society's entire repertoire of managed available to users. ${ }^{111}$ The money collected would be then redistributed to the rights holders.

[29] Actually, courts have expressed hesitations in endorsing the ECL opt-out mechanism (as seen in the Google books case). ${ }^{112}$ A recent ECJ decision ruled against this arrangement, while reviewing a French law that regulated the digital exploitation of out-of-print 20th century books. ${ }^{113}$ This French law gave approved collecting societies the right to authorize the reproduction and digital representation of out-of-print books. ${ }^{114}$ Meanwhile, the law provided authors - or their successors in title-with an opt-out mechanism subject to certain conditions. In Soulier, the ECJ declared the French law uncompliant with European law, ${ }^{115}$ which

same proposal endorsed by the French Alliance Public-Artistes, campaigning for the implementation of a Licence Globale).

${ }^{111}$ See Volker Grassmuck, A New Study Shows Copyright Exception for Legalising FileSharing is Feasible as a Cease-Fire in the "War on Copying" Emerges, Intellectual Property Watch (Nov. 5, 2009), http://www.ip-watch.org/2009/05/11/the-world-is-goingflat-rate/, archived at https://perma.cc/5XHC-K4NQ.

${ }^{112}$ See Authors Guild v. Google, Inc., 804 F.3d 202, 229 (2d Cir. 2015).

${ }^{113}$ See LOI 2012-287 du 1er mars 2012 relative à l'exploitation numérique des livres indisponibles du XXe siècle [Law 2012-287 of March 1, 2012 on the Digital Explotation of the Unavailable Books of the 20th Century], Journal OFFICIEL DE LA REPUBLIQUE FranÇAise [J.O.] [OfFiCial GAZETTE OF FRANCE], Mar. 2, 2012, p. 3986.

${ }^{114}$ See id.

${ }^{115}$ See Case C-301/15, Soulier v. Ministre de la Culture et de la Comm., Premier Ministre, 2016 CURIA.EuROPA.Eu ECLI:EU:C:2016:878 (Nov. 16, 2016) [Fr.], http://curia.europa.eu/juris/document/document.jsf?text=\&docid=185423\&pageIndex $=0$ \&doclang=EN, archived at https://perma.cc/NWH9-NXFC (involving a request for a preliminary hearing by the Council of State, regarding an action Mac Soulier and Sara 


Richmond Journal of Law \& Technology $\quad$ Volume XXIII, Issue 2

provides authors - not collecting societies - with the right to authorize the reproduction and communication to the public of their works. ${ }^{116}$ The Soulier decision might have far-reaching effects for the EU directive proposal-and more generally for all national systems of extended collective licensing that might be incompatible with EU law. The successful implementation of the directive proposal might remain the sole option to keep ECL arrangements in place by redressing this judicial interpretation

\section{Alternative Compensation Systems or Cultural Flat Rate}

[30] As Volker Grassmuck noted, "the world is going flat(-rate)." ${ }^{117}$ In search of alternative remuneration systems, researchers, activists, consumer organizations, artist groups, and policy makers have proposed to finance creativity on a flat-rate base. In the past, levies on recording devices and media have been set up upon the acknowledgment that private copying cannot be prevented. ${ }^{118}$ The same reasoning applies to the introduction of a legal permission to copy and make available copyrighted works for non-commercial purposes in the Internet. ${ }^{119}$ Flat rate proposals

Doke against the Minister of Culture and Communication, and the Prime Minister, on the interpretation of Articles 2 and 5 of a European Council Directive).

116 See id.

${ }^{117}$ Grassmuck, supra note 111.

${ }^{118}$ In the analog environment, many national legislations implemented quasi flat rate models and different arrangements of private copying levies that may be envisioned as a form of cultural tax. Private copying levies are special taxes, which are charged on purchases of recordable media and copying devices and then redistributed to the right holders by means of collecting societies. See, e.g., MARTIN KRETSCHMER, UNITED Kingdom Intellectual Prop. OfFice, Private Copying AND FAir CoMPENSATION: AN EMPIRICAL STUDY OF COPYRIGHT LEVIES IN EUROPE 64 (2011), https://papers.ssrn.com/sol3/papers.cfm?abstract_id=2063809, archived at https://perma.cc/W3QW-49FB (follow "Download this paper” hyperlink).

119 See generally Bernt Hugenholtz et al., The Future of Levies in a Digital Environment, INSTITUTE FOR INFORMATION LAW, at ii., 74 (2003), https://www.ivir.nl/publicaties/download/DRM\&levies-report.pdf, archived at https://perma.cc/APU4-SHL5. 
Richmond Journal of Law \& Technology $\quad$ Volume XXIII, Issue 2

favor a sharing ecology that is best suited to the networked information economy. ${ }^{120}$ A recent study of the Institute of European Media Law has argued that this may be "no[thing] less than the logical consequence [of] the technical revolution [introduced] by the internet." 121 The Communia study also described the minimum requirements for a cultural flat-rate as follows: "(i) a legal license permitting private individuals to exchange copyright works for non-commercial purposes; (ii) a levy, possibly collected by ISPs, flat, possibly differentiated by access speed; and (iii) a collective management, i.e. a mechanism for collecting the money and distributing it fairly." 122

[31] Several flat-rate models have been proposed. ${ }^{123}$ Some see the flatrate payment by Internet subscribers as similar to private copying levies managed by collecting societies, while others want to put in place an entirely new reward system, giving the key role to Internet users themselves. ${ }^{124}$ A non-commercial use levy permitting non-commercial file

\footnotetext{
${ }^{120}$ See generally Grassmuck, supra note 111 (exploring flat rate proposals and emerging models).

${ }^{121}$ See Alexander Roßnagel et al., Die Zulässigkeit einer Kulturflatrate nach Nationalem und Europäischem Recht [The Admissibility of a Cultural Flat Rate under National and European Law], INSTITUT FÜR EUROPÄISCHES MEDIENRECHT [INSTITUTE OF EUROPEAN MEDIA LAw], at 63 (2009), https://www.gruene-

bundestag.de/fileadmin/media/gruenebundestag_de/themen_az/netzpolitik/16_fragen_un d_16_antworten/kurzgutachten_zur_kulturflatrate.pdf, archived at https://perma.cc/6E8A-LED2.

${ }^{122}$ See id.; see COMMUNIA Network on the Digital Public Domain, Recommendation 14, in FINAL REPORT 171 (Mar. 31, 2011), http://nexa.polito.it/nexacenterfiles/D1.11-COMMUNIA\%20Final\%20Reportnov2011.pdf, archived at https://perma.cc/3XG7-NLSA).

${ }^{123}$ See e.g., Alain Modot et al., The "Content Flat-Rate": A Solution to Illegal FileSharing?, EUROPEAN PARLIAMENT, at 26 (2011), http://www.europarl.europa.eu/RegData/etudes/etudes/join/2011/460058/IPOLCULT_ET(2011)460058_EN.pdf, archived at https://perma.cc/2LWA-QTJS.

${ }^{124}$ See Neil W. Netanel, Impose A Noncommercial Use Levy To Allow Free Peer-To-Peer File Sharing, 17 HARV. J. L. \& TECH. 1, 32, 80 (2003).
} 
Richmond Journal of Law \& Technology

Volume XXIII, Issue 2

sharing of any digitized work was first proposed by Professor Neil Netanel. ${ }^{125}$ Such a levy would be imposed on the sale of any consumer electronic devices used to copy, store, send or perform shared and downloaded files, but also on the sale of internet access and P2P software and services. ${ }^{126}$ An ad hoc body would be in charge of determining the amount of the levy. ${ }^{127}$ The proceeds would be distributed to copyright holders by taking into consideration the popularity of the works measured by tracking and monitoring technologies. ${ }^{128}$ Users could freely copy, circulate, and make non-commercial use of any works that the rights holder has made available on the Internet. William Fisher followed up on Netanel with a more refined and comprehensive proposal. ${ }^{129}$ Creators' remuneration would still be collected through levies on media devices and Internet connection. ${ }^{130}$ In Fisher's system, however, a governmentally administered registrar for digital content, or alternatively a private organization, would be in charge of the management of creative works in the digital environment. ${ }^{131}$ Digitized works would be registered with the Registrar and embedded with digital watermarks. Tracking technologies would measure the popularity of the works circulating online. ${ }^{132}$ The Registrar would then redistribute the proceedings to the registered right holders according to popularity. Philippe Aigrain proposed a "creative contribution" encompassing a global license to share published digital

\footnotetext{
${ }^{125}$ See id. at 4 .

${ }^{126}$ See id.

${ }^{127}$ See id.

${ }^{128}$ See Netanal supra note 124 at 4.

${ }^{129}$ See generally William W. Fisher, Promises To KeEP: TeChNOlogy, LaW AND the FUTURE OF ENTERTAINMENT (2004).

${ }^{130}$ See id. at 217.

${ }^{131}$ See id. at 223-24.

${ }^{132}$ See id.
} 


\begin{tabular}{ll}
\hline Richmond Journal of Law \& Technology & Volume XXIII, Issue 2 \\
\hline
\end{tabular}

works in the form of ECL, or absent an agreement, of legal licensing. ${ }^{133}$ Remuneration would be provided by a flat-rate paid by all Internet subscribers. ${ }^{134}$ Half of the money collected would be used for the remuneration of works shared over the Internet - distributed according to their popularity. ${ }^{135}$ Measurement of popularity would be based on a large panel of voluntary Internet users transmitting anonymous data on their usage to collective management societies. ${ }^{136}$ The other half of the money collected would be devoted to funding the production of new works and the promotion of added-value intermediaries in the creative environment. ${ }^{137}$ Another suggestion included among flat-rates models is Peter Sunde's Flattr "micro-donations" scheme. An internet user would give between 2 and 100 euros per month and could then nominate works that they wish to reward or "flattr," a play on the words "flatter" and "flatrate." 138 Finally, the "German and European Green Parties included in their policy agenda the promotion of a cultural flat rate to decriminalise P2P users, remunerate creativity and relieve the judicial system and the ISPs from mass-scale prosecution." 139 The "Green Party's proposal has been backed up by the mentioned EML study that found that a levy on Internet usage legalizing non-commercial online exchanges of creative works conforms with German and European copyright law, even though it requires changes in both."

\footnotetext{
${ }^{133}$ See Philippe Aigrain with SuZAnne Aigrain, Sharing: Culture AND the ECONOMY IN THE INTERNET AGE 76-77 (2012).

${ }^{134}$ See id. at 65.

${ }^{135}$ See id .

${ }^{136}$ See id at $152-53$.

${ }^{137}$ See id.

${ }^{138}$ See Re:publica, Peter Sunde - Flattr Social Micro Donations, YouTube (Apr. 22, 2010), https://www.youtube.com/watch?v=IyGCsCpofVk, archived at https://perma.cc/TN7J-7VCK (describing the Flattr platform); see also FLATTR, https://flattr.com/, archived at https://perma.cc/Y3C7-X3KP (last visited Feb. 9, 2017).

${ }^{139}$ COMMUNIA, Recommendation 14, supra note 121, at 171.

${ }^{140} I d$.
} 


Richmond Journal of Law \& Technology $\quad$ Volume XXIII, Issue 2

\section{The ACCess 2 KNowledge (A2K) Movement}

[32] As Nelson Mandela once noted, "[e]liminating the distinction between the information rich and information poor is...critical to eliminating economic and other inequalities between North and South, and to improving the life of all humanity."141 "Access to learning and knowledge....[are] key elements towards the improvement of the situation of under-privileged countries..."142 Extreme copyright expansion and constant cultural appropriation, together with a dysfunctional access to scientific and patented knowledge, heightened the North-South cultural divide. The Global South has been exposed to the effects of a pernicious form of cultural imperialism, without the advantages of freely reusing that culture for its own growth. The Vatican noted that

[o]n the part of rich countries there is excessive zeal for protecting knowledge through an unduly rigid assertion of the right to intellectual property, especially in the field of health care. At the same time, in some poor countries, cultural models and social norms of behaviour persist which hinder the process of development. ${ }^{143}$

[33] The issue of access to knowledge was first publicly expressed by the Brazilian government in a 1961 draft resolution. ${ }^{144}$ Since then, access

\footnotetext{
${ }^{141}$ Nelson Mandela, Remarks Made at the TELECOM 95 Conference, 3 Oct. 1995, 9 TROTTER REV. 4, 4 (1995).

${ }^{142}$ World InTEllectual Property Organization (WIPO), Provisional COMmitTeE on Proposals Related to a WIPO Development Agenda (PCDA), Revised Draft Report, at 6 (Aug. 20, 2007), http://www.wipo.int/edocs/mdocs/mdocs/en/pcda_4/pcda_4_3.pdf, archived at https://perma.cc/Y9AK-YNH5.

${ }^{143}$ Benedict XVI, Caritas In Veritate [Encyclical Letter on Good Will on Integral Human Development in Charity and Truth], sec. 22 (June 29, 2009) available at $\mathrm{http} / /$ w2.vatican.va/content/benedict-xvi/en/encyclicals/documents/hf_benxvi_enc_20090629_caritas-in-veritate.html, archived at https://perma.cc/K7YL-9ZB8.

${ }^{144}$ See Graham Dutfield and Uma Suthersanen, Global InTELleCtual Property LAW 277 (2008).
} 
to knowledge has recently returned to become a question of major international concern. Access to Knowledge (A2K) is a globalized movement aimed at promoting redistribution of informational resources in favor of minorities and the Global South. ${ }^{145}$ In 2006, the Yale Information Society Project held an A2K conference committed "to building a broad conceptual framework of 'Access to Knowledge' that can foster powerful coalitions between diverse groups." "146 Yale's 2007 A2K conference aimed to "further build the coalition amongst institutions and stakeholders" from the 2006 conference. ${ }^{147}$ The Consumer Project on Technology (CPT) says that $\mathrm{A} 2 \mathrm{~K}$ :

takes concerns with copyright law and other regulations that affect knowledge and places them within an understandable social need and policy platform: access to knowledge goods...The rich and the poor can be more equal with regard to knowledge goods than to many other areas. $^{148}$

[34] Under the umbrella of Article 27 of the Universal Declaration of Human Rights, several working projects at the international level have been set up to address the requests of the A2K movement. ${ }^{149}$ As part of the

\footnotetext{
145 See Amy Kapczynski, The Access to Knowledge Mobilization and The New Politics of Intellectual Property, 117 YALE L. J. 804, 807-08 (2008); see generally ACCESS TO KNOWLEdGe In the Age OF InTEllectual Property (Gaëlle Krikorian and Amy Kapczynski eds., Zone Books 2010); see also ACCESS TO KNOWLEDGE IN AFRICA: THE ROLE OF COPYRIGHT (Chris Armstrong et al. eds., UCT Press 2010) (showing an example of the body of work created by pro-A2K groups).

${ }^{146}$ Conference, 2nd Annual Access to Knowledge Conference (A2K2), YALE INFORMATION SOCIETY PROJECT (2007), http://mailman.yale.edu/pipermail/developmentstudies/2007-April/000074.html, archived at https://perma.cc/5A2K-8MPE.

${ }^{147} I d$.

${ }^{148}$ CONSUmer Project On TeChnOlogy, AcCess to KNOWLEDGe, http://www.cptech.org/a2k, archived at https://perma.cc/H2AR-GG39.

${ }^{149}$ See G.A. Res. 217 (III) A, Universal Declaration of Human Rights (Dec. 10, 1948), http://www.un.org/en/universal-declaration-human-rights/, archived at https://perma.cc/RH3X-86MJ (follow “Download PDF”).
} 


Richmond Journal of Law \& Technology $\quad$ Volume XXIII, Issue 2

discussions leading to the adoption of the WIPO Development Agenda, ${ }^{150}$ activists produced a document to start negotiations on a Treaty on Access to Knowledge. ${ }^{151}$ The proposed treaty is based on the core idea that "restrictions on access ought to be the exception, not the other way around," and that "both subject matter exclusions from, and exceptions and limitations to, intellectual property protection standards are mandatory rather than permissive." 152 Unfortunately, consensus on the A2K Treaty is still an ephemeral mirage. Though, after a long battle, ${ }^{153}$ a narrow version of the A2K Treaty, to promote the use of protected works by disabled persons was signed in Marrakesh in 2013. ${ }^{154}$

[35] The quest for access to knowledge goes hand in hand with the desire of the Global South and minorities to reclaim cultural identity from

\footnotetext{
${ }^{150}$ See WIPO, DEVELOPMENT AGENDA FOR WIPO, http://www.wipo.int/ipdevelopment/en/agenda, archived at $\mathrm{https} / / /$ perma.cc/NW6Y-F465.

${ }^{151}$ See CPTech, Proposed Treaty on AcCess to Knowledge (May 9, 2005) (Draft), www.cptech.org/a2k/a2k_treaty_may9.pdf, archived at https://perma.cc/33E5-77GE.

${ }^{152}$ Laurence R. Helfer, Toward a Human Rights Framework for Intellectual Property, 40 U.C. DAVIS L. REV. 971, 1013 (2007) (citing William New, Experts Debate Access to Knowledge, IP WATCH (2005) http://www.ip-watch.org/2005/02/15/experts-debateaccess-to-knowledge/?res), archived at https://perma.cc/7QJA-DJBQ; see also Proposed A2K Treaty, supra note 151 (mentioning other actions to achieve A2K goals, such as the use of the Internet as a tool for broader public participation; preservation of public domain; control of anticompetitive practices; restriction of the use of TPMs limiting A2K; use of educational material made available at an unreasonable price; and a new role of fair use, especially for purposes including but not limited to parody, reverse engineering and use of works by disabled person).

${ }^{153}$ See, e.g., Margot E. Kaminski \& Shlomit Yanisky-Ravid, Working Paper: Addressing the Proposed WIPO International Instrument on Limitations and Exceptions for Persons with Print Disabilities: Recommendation or Mandatory Treaty?, YALE INFORMATION SOCIETY 6 (Nov. 14, 2011), http://papers.ssrn.com/sol3/papers.cfm?abstract_id=1959694, archived at https://perma.cc/4TXL-XBLZ (follow “Download This Paper” hyperlink).

${ }^{154}$ See Marrakesh Treaty to Facilitate Access to Published Works for Persons Who Are Blind, Visually Impaired or Otherwise Print Disabled, July 27, 2013, WIPO, (entered into force Sept. 30, 2016).
} 


Richmond Journal of Law \& Technology $\quad$ Volume XXIII, Issue 2

imperialist power. The search for cultural distinctiveness and access to knowledge becomes a paradigm of equality. ${ }^{155}$ Although international agreement from all stakeholders on an A2K Treaty may be hard to reach, grass-roots movements spearheaded similar goals through different routes. A quest for open access to academic knowledge occupied the recent agenda of a global network of institutions and stakeholders.

\section{From "ELITE-NMENT" TO OPEN KNOWLEDGE ENVIRONMENTS}

[36] In a momentous speech at the European Organization for Nuclear Research (CERN) in Geneva, Professor Lawrence Lessig reminded the audience of scientists and researchers that most scientific knowledge is locked away for the general public and can only be accessed by professors and students in a university setting. ${ }^{156}$ Lessig pungently made the point that "if you are a member of the knowledge elite, then there is free access, but for the rest of the world, not so much...publisher restrictions do not achieve the objective of enlightenment, but rather the reality of 'elitenment." 157

[37] Other authors have reinforced this point. John Willinsky, for example, suggested that, as its key contribution, open access publishing (OAP) models may move "knowledge from the closed cloisters of privileged, well-endowed universities to institutions worldwide." ${ }^{158}$ As

\footnotetext{
${ }^{155}$ See Joost Smiers \& Marieke Van Schijndel, Imagine There is no Copyright and No Cultural Conglomerates too, 4 INSTITUTE OF NETWORK CULTURES 5, 26; see also JOHANNA GIBSON, COMMUNITY RESOURCES: INTELLECTUAL PROPERTY, INTERNATIONAL Trade AND Protection of TRADITIONAL KNOWLEDGE 127-28 (2005).

${ }^{156}$ See Lawrence Lessing, The Architecture of Access to Scientific Knowledge: Just How Badly We Have Messed This Up, Address at CERN Colloquium and Library Science Talk, (Apr. 18, 2011), http://cdsweb.cern.ch/record/1345337, archived at https://perma.cc/L5TM-PVLB; see also Lawrence Lessig, Recognizing the Fight We're In, Address at the Open Rights Group Conference, (Mar. 24, 2012), http://vimeo.com/39188615, archived at https://perma.cc/9NSW-YD28.

${ }^{157}$ Lessing, CERN Colloquium Address, supra note 156.

${ }^{158}$ JoHN WILlinsky, THe ACCESS PRINCIPLE: THE CASE FOR OPEN ACCESS TO RESEARCH AND SCHOLARSHIP 33, (2006).
} 
Richmond Journal of Law \& Technology $\quad$ Volume XXIII, Issue 2

Willinsky noted, "[o]pen access could be the next step in a tradition that includes the printing press and penny post, public libraries and public schools. It is a tradition bent on increasing the democratic circulation of knowledge..." ${ }^{\prime 59}$ There is a common understanding that the path to digital enlightenment may start with open access to scientific knowledge.

[38] The open access movement in scholarly publishing was inspired by the dramatic increase in prices for journals and publisher restrictions to the reuse of information. ${ }^{160}$ The academics' reaction against the 'cost of knowledge' - also known as the serial crisis - is on the rise, especially against the practice of charging "exorbitantly high prices for...journals," and of "agree[ing] to buy very large "bundles.",161 As Reto Hilty noted, the price increase of publishers' products-while publishers' costs have sunk dramatically - has forced the scientific community to react by implementing open access options, because antiquated copyright laws have failed to bring about reasonable balance of interests. ${ }^{162}$ George Monbiot stressed the unfairness of the academic publishing system by noting, with specific reference to publishers such as Elsevier, Springer, or Wiley-Blackwell:

\footnotetext{
${ }^{159} I d$. at 30 .

${ }^{160}$ See Giancarlo F. Frosio, Open Access Publishing: A Literature Review 74 (study prepared for the RCUK Centre for Copyright and New Business Models in the Creative Economy) (2014), http://www.create.ac.uk/publications/open-access-publishinga-literature-review, archived at https://perma.cc/FLJ4-ELXA (providing a book length overview of the OAP movement and several open access initiatives and projects, economics of academic publishing and copyright implications, OAP business models, and OAP policy initiatives).

${ }^{161} 16538$ Researchers Taking a Stand, THE COST OF KNOWLEDGE, http://thecostofknowledge.com, archived at https://perma.cc/YH5Z-JNDG; see also The Price of Information: Academics are Starting to Boycott a Big Publisher of Journals, THE ECONOMIST, Feb. 4 2012, http://www.economist.com/node/21545974, archived at https://perma.cc/L3BX-MU35; see also Eyal Amiran, The Open Access Debate, 18 SYMPLOKE 251, 251 (2011) (reporting several other example of these reactions and boycotts).

${ }^{162}$ See Reto M. Hilty, Copyright Law and the Information Society - Neglected Adjustments and Their Consequences, 38(2) ICC 135 (2007).
} 


Richmond Journal of Law \& Technology $\quad$ Volume XXIII, Issue 2

[w]hat we see here is pure rentier capitalism: monopolising a public resource then charging exorbitant fees to use it. Another term for it is economic parasitism. To obtain the knowledge for which we have already paid, we must surrender our feu to the lairds of learning.

[39] The parasitism lies in a monopoly over content that the academic publishers do not create and do not pay for. Researchers, hoping publish with reputable journals, surrender their copyrights for free. ${ }^{164}$ Most of the time, the production of that very content-now monopolized by the academic publishers - was funded by the public, through government research grants and academic incomes. ${ }^{165}$ This led some authors to discuss the opportunity of abolishing copyright for academic works all together. ${ }^{166}$ From the ancient proverbial idea of scientia donum dei est unde vendi non potest to the emergence of the notion of 'open science', the normative structure of science presents an unresolvable tension with the exclusive and monopolistic structure of intellectual property entitlements. Merton powerfully emphasized the contrast between the ethos of science and intellectual property monopoly rights:

"Communism," in the nontechnical and extended sense of common ownership of goods, is a second integral element of the scientific ethos. The substantive findings of science are a product of social collaboration and are assigned to the community. They constitute a common heritage in which

\footnotetext{
${ }^{163}$ George Monbiot, Academic Publishers Make Murdoch Look like a Socialist, THE GuARDiAn, (Aug. 29, 2011 4:08 PM),

http://www.guardian.co.uk/commentisfree/2011/aug/29/academic-publishers-murdochsocialist, archived at https://perma.cc/4NZ7-3X4S; see also Richard Smith, The Highly Profitable but Unethical Business of Publishing Medical Research, 99 J. R. Soc. MED. 452-53 (2006) (discussing in similarly strong terms the unethical nature of the business of publishing medical research).

${ }^{164}$ See Richard Smith, supra note 163 at 452.

${ }^{165}$ See id. at 454.

${ }^{166}$ See, e.g., Steven Shavell, Should Copyright of Academic Works Be Abolished?, 2 J. LEGAL ANALYSIS 301, 301-05 (2010).
} 


Richmond Journal of Law \& Technology $\quad$ Volume XXIII, Issue 2

the equity of the individual producer is severely limited. An eponymous law or theory does not enter into the exclusive possession of the discoverer and his heirs, nor do the mores bestow upon them special rights of use and disposition. Property rights in science are whittled down to a bare minimum by the rationale of the scientific ethic. The scientist's claim to "his" intellectual "property" is limited to that of recognition and esteem which, if the institution functions with a modicum of efficiency, is roughly commensurate with the significance of the increments brought to the common fund of knowledge. ${ }^{167}$

[40] The major propulsion to open access at the European level was driven by the Berlin Conferences. The first Berlin Conference was organized in 2003 by the Max Planck Society and the European Cultural Heritage Online (ECHO) project to discuss ways of providing access to research findings. ${ }^{168}$ Annual follow-up conferences have been organized ever since. The most significant result of the Berlin Conference was the Berlin Declaration on Open Access to Knowledge in the Sciences and Humanities ("Berlin Declaration"), including the goal of disseminating knowledge through the open access paradigm via the Internet. ${ }^{169}$ The

\footnotetext{
${ }^{167}$ Robert K. Merton, The Normative Structure of Science, in THE SOCIOLOGY OF SCIENCE: THEORETICAL AND EMPIRICAL InVESTIGATIONS 267, 273 (Norman W. Storer ed., U. Chicago Press 1973) (1942) (emphasis added), http://www.collier.sts.vt.edu/5424/pdfs/merton_1973.pdf, archived at https://perma.cc/UZ2S-9D7G; see also James Boyle, Mertonianism Unbound? Imagining Free, Decentralized Access to Most Cultural and Scientific Material, in UnDERSTANDING Knowledge AS a COMmons: From Theory to Practice 123 (Charlotte Hess \& Elinor Ostrom eds., MIT Press 2007),

http://www.ess.inpe.br/courses/lib/exe/fetch.php?media=wiki:user:andre.zopelari:underst anding-knowledge-as-a-commons-theory-to-practice-2007.pdf, archived at https://perma.cc/5LFJ-FBAP.

${ }^{168}$ See Berlin Declaration on Open Access to Knowledge in the Sciences and Humanities (October 22, 2003), Berlin Conference, Berlin, October 20-22, 2003, https://openaccess.mpg.de/Berlin-Declaration, archived at https://perma.cc/3K38MDXW.

${ }^{169}$ See id.
} 
Richmond Journal of Law \& Technology $\quad$ Volume XXIII, Issue 2

Berlin Declaration has been signed by hundreds of European and international institutions. OAP is a publishing model where the research, institution or the party financing the research pays for publication and the article is then freely accessible. In particular, OAP refers to free and unrestricted world-wide electronic distribution and availability of peerreviewed journal literature. ${ }^{170}$ The Budapest Open Access Initiative uses a definition that includes free reuse and redistribution of "[o]pen [a]ccess" material by anyone. ${ }^{171}$ According to Peter Suber, the de facto spokesperson of the OAP movement,

Open access $(\mathrm{OA})$ is free online access. OA literature is not only free of charge to everyone with an Internet connection, but free of most copyright and licensing restrictions. OA literature is barrier-free literature produced by removing the price barriers and permission barriers that block access and limit usage of most conventionally published literature, whether in print or online. ${ }^{172}$

[41] Since the inception of the open-access initiative in 2001, there are now almost eleven thousand open access journals and their number is constantly rising. ${ }^{173}$ In addition, several leading international academic institutions endorsed open-access policies and are working towards mechanisms to cover open-access journals' operating expenses. ${ }^{174}$ The

\footnotetext{
${ }^{170}$ See id.

${ }^{171}$ Budapest Open Access Initiative, BUDAPEST OPEN ACCESS INITITATIVE, http://www.soros.org/openaccess/index.shtml, archived at https://perma.cc/LZZ3-6CVD.

${ }^{172}$ Peter Suber, Creating an Intellectual Commons Through Open Access, in Understanding KNOWledge as a COMmONS: From Theory to PraCtice 171 (Charlotte Hess \& Elinor Ostrom eds., MIT Press 2006).

${ }^{173}$ See Directory of Open Access Journals(DOAJ), DOAJ (last visited Feb. 9, 2017), http://www.doaj.org, archived at https://perma.cc/26KJ-NKFY.

${ }^{174}$ See Open Access, The Scholarly Publishing \& ACADEMic Resources CoAlition [SPARC], http://www.arl.org/sparc/advocacy/campus, archived at https://perma.cc/6RPN-BQJ2; see also SHERPA/JULIET - Research funders' open access policies, SHERPA (last visited Feb. 9, 2017), http://www.sherpa.ac.uk/juliet/index.php, archived at https://perma.cc/T7HW-XXJD; see
} 


Richmond Journal of Law \& Technology $\quad$ Volume XXIII, Issue 2

same approach is increasingly followed by governmental institutions, ${ }^{175}$ in light of the fact that economic studies have shown a positive net value of OAP models when compared to other publishing models. ${ }^{176}$ The European Commission, for example, plans to make OAP the norm for research receiving founding from its Horizon 2020 programme - the EU framework programme for research and innovation. ${ }^{177}$ As part of its Innovation and Research Strategy for Growth, the UK government has announced that all publicly funded scientific research must be published in open-access journals. ${ }^{178}$ In the US, several research funding agencies have instituted open access conditions. ${ }^{179}$ After an initial voluntary adoption in

also Manual of Policies and Procedures - F/1.3 QUT ePrints repository for research output, QUEENSLAND UNIV. OF TECH. [QUT] (Apr. 6, 2016),

http://www.mopp.qut.edu.au/F/F_01_03.jsp, archived at https://perma.cc/97KW-FJ62;

see also Eric Priest, Copyright and The Harvard Open Access Mandate, 10 Nw. J. TeCH. \& INTELL. PROP. 377, 394 (2012).

${ }^{175}$ See Frosio, OPEN ACCESS PUBLISHING, supra note 160, at 9.

${ }^{176}$ See John Houghton, Open Access - What are the Economic Benefits?, VICTORIA UNIVERSITY, 13 (June 23, 2009) (report prepared for Knowledge Exchange) (showing that adopting an open access model to scholarly publications could lead to annual savings of around $€ 70$ million in Denmark, $€ 133$ million in the Netherlands and $€ 480$ million in the United Kingdom); see also John Houghton et al., Economic and Social Returns on Investment in Open Archiving Publicly Funded Research Outputs, VICTORIA UnIVERSITY, 12 (July 2010) (report prepared for The Scholarly Publishing \& Academic Resources Coalition [SPARC]) (concluding that free access to U.S. taxpayer-funded research papers could yield $\$ 1$ billion in benefits).

${ }^{177}$ See What is Horizon 2020?, EUROPEAN COMMISSION, $\mathrm{http} / /$ ec.europa.eu/programmes/horizon2020/en/what-horizon-2020, archived at https://perma.cc/GHF3-YSEC.

${ }^{178}$ See DEPARTMENT FOR BUSINESS INNOVATION AND SKILLS, INNOVATION AND RESEARCH STRATEGY FOR GROWTH 76-78 (Dec. 8, 2011), http://www.bis.gov.uk/assets/biscore/innovation/docs/i/11-1387-innovation-and-researchstrategy-for-growth.pdf, archived at https://perma.cc/QD5R-RGN8; see also Finch Report: Report of the Working Group on Expanding Access to Published Research Findings, Accessibility, Sustainability, Excellence: How to Expand Access to Research Publications, RESEARCH INFORMATION NETWORK, https://www.acu.ac.uk/researchinformation-network/finch-report, archived at https://perma.cc/Q287-FXA5.

${ }^{179}$ See U.S. Department of EdUCATION, Institute of EDUCATION SCIENCES (IES), Request for Application, IES 11 (2009), http://ies.ed.gov/funding/pdf/2010_84305G.pdf, 


\begin{tabular}{ll}
\hline Richmond Journal of Law \& Technology & Volume XXIII, Issue 2 \\
\hline
\end{tabular}

2005, the Consolidated Appropriations Act of $2008^{180}$ instituted an open access mandate for research projects funded by the NIH. ${ }^{181}$ So far, the NIH has reported a compliance rate of $75 \%{ }^{182}$ Together with research articles, data, teaching materials, and the like, the importance of open access models extends also to books. Millions of historic volumes are now openly accessible from various digitization projects such as Europeana, Google Books, or Hathi. In addition, many recent volumes are also openly available from a variety of academic presses, government and nonprofit agencies, and other individuals and groups. Libraries' cataloging data are increasingly released under open access models. ${ }^{183}$

archived at https://perma.cc/HYW2-8B74; see also New Open Access Policy for NCAR Research, ATMOSNEWs (October 20, 2009), https://www2.ucar.edu/atmosnews/news/1059/new-open-access-policy-ncar-research, archived at https://perma.cc/JEP9-FGST; see also HOWARD HUGHES MEDICAL Institute, Research Policies: Public Access to Publications 1 (June 11, 2007), http://www.hhmi.org/sites/default/files/About/Policies/sc320.pdf, archived at https://perma.cc/7CJP-3NYT.

${ }^{180}$ See Consolidated Appropriations Act of 2008, H.R. 2764, $110^{\text {th }}$ Cong. Div. G, II $\S$ 218; see also Eve Heafey, Public Access to Science: The New Policy of The National Institutes of Health in Light of Copyright Protections in National and International Law, 15 UCLA J. L. \& Tech. 1, 3 (2011),

http://www.lawtechjournal.com/articles/2010/02_100216_heafey.pdf, archived at . https://perma.cc/M93U-HQA6.

${ }^{181}$ See National Institute of Health, Revised Policy on Enhancing Public Access to Archived Publications Resulting from NIH-Funded Research, (Jan. 11, 2008), http:/grants.nih.gov/grants/guide/notice-files/NOT-OD-08-033.html, archived at https://perma.cc/UGB3-QR38; see also Peter Suber, An Open Access Mandate for the National Institutes of Health, 2(2) OPEN MEDICINE e39-e41 (2008), https://www.ncbi.nlm.nih.gov/pmc/articles/PMC3090178/, archived at https://perma.cc/H8M5-NFN6.

182 See Richard Poynder, Open Access Mandates: Ensuring Compliance, OPEN AND SHUT? (May 18, 2012), http://poynder.blogspot.fi/2012/05/open-access-mandatesensuring.html, archived at https://perma.cc/LWT5-F6SB.

${ }^{183}$ See, e.g., Adrian Pohl, Launch of the Principles on Open Bibliographic Data, OPEN KNOWLEDGE INTERNATIONAL BLOG (Jan. 18, 2011), http://blog.okfn.org/2011/01/18/launch-of-the-principles-on-open-bibliographic-data/, archived at https://perma.cc/DCY7-VNPL. 
Richmond Journal of Law \& Technology $\quad$ Volume XXIII, Issue 2

[42] Criticizing the university for having become part of the problem of enclosure of scientific commons by "avidly defending their rights to patent their research results, and licence as they choose," Richard Nelson argues that "the key to assuring that a large portion of what comes out of future scientific research will be placed in the commons is staunch defense of the commons by universities." 184 Nelson continues by arguing that if universities "have policies of laying their research results largely open, most of science will continue to be in the commons." ${ }^{185}$ There is a true responsibility of the academic community towards expanding OAP. The role of universities in the open access and OAP movement is critical and more than any other institutions they have motive to promote the goals of "open science." Willinsky advocated the idea that scholars have a responsibility to make their work available OA globally by referring to an 'access principle' and noting that " $[a]$ commitment to the value and quality of research carries with it a responsibility to extend the circulation of such work as far as possible and ideally to all who are interested in it and all who might profit by it." ${ }^{186}$ In this sense, the true challenge ahead of the OAP movement is to turn university environments, and the knowledge produced within, into a more easily and freely accessible public good, perhaps better integrating the OAP movement with Open University and Open Learning.

[43] Seeking to reap the full value that open access can yield in the digital environment, Jerome Reichman and Paul Uhlir proposed a model of open knowledge environments (OKEs) for digitally networked scientific communication. ${ }^{187}$ OKEs would "bring the scholarly

\footnotetext{
${ }^{184}$ Richard R Nelson, The Market Economy, and the Scientific Commons, 33 RESEARCH POLICY 455, 467 (2004), http://dimetic.dime-eu.org/dimetic_files/NelsonRP2004.pdf, archived at https://perma.cc/SP3Z-Y7NT.

${ }^{185} I d$.

${ }^{186}$ WiLlinSKY, supra note 158, at xii; see also PETER SUBER, OPEn ACCESS (MIT Press 2012) (discussing the emergence of this principle).

${ }^{187}$ See Jerome H. Reichman, Tom Dedeurwaerdere, \& Paul F. Uhlir, Governing Digitally INTEGRATEd GeNETIC RESOURCES, DATA AND LiterATURE: GLOBAL INTELLECTUAL PROPERTY STRATEGIES FOR A REDESIGNED MiCROBIAL RESEARCH COMMONS 441 (Cambridge U. Press, 2016).
} 


Richmond Journal of Law \& Technology $\quad$ Volume XXIII, Issue 2

communication function back into the universities" through "the development of interactive portals focused on knowledge production and on collaborative research and educational opportunities in specific thematic areas." ${ }^{188}$ Also, OKEs might reshape the role of libraries. As mentioned earlier, libraries are knowledge infrastructures and should be one of the main drivers of access to knowledge in the digital networked society. However, extreme commodification of information, propelled by the present legal framework, may drive libraries away from their function as knowledge repositories. As Guy Pessach noted,

[1]ibraries are increasingly consuming significant shares of their knowledge goods from globalized publishers according to the contractual and technological protection measures that these publishers impose on their digital content. Thus there is an unavoidable movement of enclosure regarding the provision of knowledge through libraries, all in a manner that practically compels libraries to take part in the privatization of knowledge supply and distribution. ${ }^{189}$

[44] Therefore, the road to global access to knowledge is to provide digital libraries with a better framework to support their independence from the increasing commodification of knowledge goods. Several preliminary steps have been taken in the context of articles 3-1(V) and 31(VIII) of the WIPO A2K draft treaty and other legal instruments. ${ }^{190} \mathrm{~A}$

\footnotetext{
${ }^{188}$ Paul F. Uhlir, Revolution and Evolution in Scientific Communication: Moving from Restricted Dissemination of Publicly-Funded Knowledge to Open Knowledge Environments, Paper Presented at the $2{ }^{\text {nd }}$ COMMUNIA Conference (June 28, 2009) (on file with COMMUNIA), http://www.communiaproject.eu/communiafiles/Conf\%202009_P_Uhlir_BS.pdf, archived at https://perma.cc/9AQS-B52J.

${ }^{189}$ Pessach Guy, The Role of Libraries in A2K: Taking Stock and Looking Ahead, 2007 Mich. ST. L. ReV. 257, 267 (2007).

${ }^{190}$ See Proposed WIPO A2K Treaty, supra note 151, at 5; see also Orphan Works Directive, supra note 90 (enabling the use of orphan works after diligent search for public libraries digitization projects); see also Case C-117/13, Technische Universität Darmstadt v Eugen Ulmer KG, 2014 E.C.R. 23 (September 11, 2013) (stating that European
} 


Richmond Journal of Law \& Technology $\quad$ Volume XXIII, Issue 2

World Digital Public Library that integrates OKEs will push forth the rediscovery of currently unused or inaccessible works, open up the riches of knowledge in formats that are accessible to persons with disabilities, and empower a superior democratic process by favoring access regardless of users' market power.

\section{The Emergence of The Public Domain ${ }^{191}$}

[45] As Jessica Litman noted, "a vigorous public domain is a crucial buttress to the copyright system; without the public domain, it might be impossible to tolerate copyright at all. ${ }^{, 192}$ The increasing enclosure of the public domain has contributed to the crisis of acceptance in which copyright law is fallen. The emergence and recognition of the public domain, the development of a public domain project, and the advent of a movement for cultural environmentalism are key elements to the resistance to copyright over-expansion. More fundamentally perhaps, the emphasis over the importance of the public domain has gained momentum together with the rise of the networked information economy and its ethical revolution emphasizing mass collaboration, sharing economy and gift exchange. In this respect, Daniel Drache noted that the emergence of the public domain and public goods in the globalized society have increasingly troubled the future prospects of 'market fundamentalism. ${ }^{, 193}$

libraries may digitize books in their collection without permission from the rightholders with caveats); see also Act of September 11, 2015, on Amendments to the Copyright and Related Rights Act and Gambling Act (Poland) (bringing library services in Poland into the twenty-first century by enabling digitization for socially beneficial purposes, such as education and preservation of cultural heritage).

${ }^{191}$ Portions of the analysis in this Section can also be found in the COMmUNIA FINAL REPORT, supra note 69.

192 Jessica Litman, The Public Domain, 39 EMORY L. J. 965, 977 (1990).

${ }^{193}$ See Daniel Drache, Introduction: The Fundamentals of Our Time - Values and Goals that are Inescapably Public, in THE MARKET OR THE PUBLIC DOMAIN?: GLOBAL

GOVERNANCE AND THE ASYMMETRY OF POWER 1 (Daniel Drache ed., Routledge 2000). 
Richmond Journal of Law \& Technology $\quad$ Volume XXIII, Issue 2

[46] Authors suggested that the Statute of Anne actually created the public domain, by limiting the duration of protected works and by introducing formalities. ${ }^{194}$ However, in early copyright law, there was no positive term to affirmatively refer to the public domain, though terms like publici juris or propriété publique had been employed by $18^{\text {th }}$ century jurists. ${ }^{195}$ Nonetheless, the fact of the public domain was recognized, though no single locution captured that concept. Soon, the idea of the public domain evolved into a "discourse of the public domain - that is, the construction of a legal language to talk about public rights in writings." ${ }^{~} 196$ Historically, the term public domain was firstly employed in France by the mid- $19^{\text {th }}$ century to mean the expiration of copyright. ${ }^{197}$ The English and American copyright discourse borrowed the term around the time of the drafting of the Berne Convention with the same meaning. ${ }^{198}$ "Traditionally, the public domain has been defined in relation to copyright as the opposite of property, as the "other side of the coin of copyright" that "is best defined in negative terms". ${ }^{199}$ This traditional definition regarded the public domain as a "wasteland of undeserving detritus" and did not "worry about 'threats' to this domain any more than [it] would worry about scavengers who go to garbage dumps to look for abandoned property." 200 This is no more. This definitional approach has been discarded in the last thirty years.

\footnotetext{
${ }^{194}$ See Jane C. Ginsburg, "Une Chose Publique”? The Author's Domain and the Public Domain in Early British, French and US Copyright Law, 65 CAMBRIDGE L. J. 636, 642 (2006).

${ }^{195} I d$. at 638 .

${ }^{196}$ Mark Rose, Nine-Tenths of the Law: The English Copyright Debates and the Rhetoric of the Public Domain, 66 LAW \& CONTEMP. PROBS. 75, 77 (2003).

${ }^{197}$ See Ginsburg, supra note 194, at 637-38.

${ }^{198}$ See id. at 637.

${ }^{199}$ M. William Krasilovsky, Observations on Public Domain, 14 BULL. COPYRIGHT SOC'Y 205 (1967).

${ }^{200}$ Pamela Samuelson, Mapping the Digital Public Domain: Threats and Opportunities, 66 LAW \& CONTEMP. PROBS. 147, 147 (2003).
} 


Richmond Journal of Law \& Technology $\quad$ Volume XXIII, Issue 2

[47] In 1981, Professor David Lange published his seminal work, Recognizing the Public Domain, and departed from the traditional line of investigation of the public domain. Lange suggested that "recognition of new intellectual property interests should be offset today by equally deliberate recognition of individual rights in the public domain." ${ }^{201}$ Lange called for an affirmative recognition of the public domain and drafted the skeleton of a new theory for the public domain. The public domain that Lange had in mind would become a "sanctuary conferring affirmative protection against the forces of private appropriation" that threatened creative expression. ${ }^{202}$ The affirmative public domain was a powerfully attractive idea for scholarly literature and civic society. Lange spearheaded a "conservancy model," concerned with promoting the public domain and protecting it against any threats, that juxtaposed the traditional "cultural stewardship model" which regarded ownership as the prerequisite of productive management. ${ }^{203}$ The positive identification of the public domain propelled the "public domain project," as Michael Birnhack called it. $^{204}$

[48] Many authors attempted to define, map, and explain the role of the public domain as an alternative to the commodification of information that threatened creativity. ${ }^{205}$ This ongoing public domain project offers many definitions that attempt to positively construe the public domain. In any event, a positive, affirmative definition of the public domain is fluid by

${ }^{201}$ David Lange, Recognizing The Public Domain, 44 LAW \& CONTEMP. ProBs. 147, 147 (1981).

\footnotetext{
${ }^{202}$ See Lange, Reimagining The Public Domain, supra note 42 at 466.

${ }^{203}$ Julie E. Cohen, Copyright, Commodification, and Culture: Locating the Public Domain, in The FUtURE OF THE PUBlic DOMAIN: IDENTIFYING THE COMMONS IN INFORMATION LAW 133-34 (Lucie Guibault \& P. Bernt Hugenholtz eds., Kluwer Law International 2006).

${ }^{204}$ Michael D. Birnhack, More or Better? Shaping the Public Domain, in THE FUTURE OF THE PUBLIC DOMAIN: IDENTIFYING THE COMMONS IN INFORMATION LAW 59-60 (Lucie Guibault \& P. Bernt Hugenholtz eds., Kluwer Law International 2006).

${ }^{205}$ See e.g., id.
} 


Richmond Journal of Law \& Technology $\quad$ Volume XXIII, Issue 2

nature. An affirmative definition of the public domain is a political statement, the endorsement of a cause. In other words, "[t]he public domain will change its shape according to the hopes it embodies, the fears it tries to lay to rest, and the implicit vision of creativity on which it rests. There is not one public domain, but many."206 Notwithstanding many complementary definitions, consistency is found in the common idea that the "materials that compose our cultural heritage must be free for all to use no less than matter necessary for biological survival. ${ }^{207}$ As a corollary, many modern definitions of the public domain are unified by concerns over recent copyright expansionism. The common understanding of the participants to the public domain project is that enclosure of the "materials that compose our cultural heritage" is a welfare loss against which society at large must be guarded from. ${ }^{208}$ The modern definitional approach endorsed by the public domain project is intended to turn the old metaphor, describing the public domain as what is "left over after intellectual property had finished satisfying its appetite, ${ }^{209}$ upside down by thinking of copyright as "a system designed to feed the public domain providing temporary and narrowly limited rights....all with the ultimate goal of promoting free access." ${ }^{, 10}$ Moreover, the public domain envisioned by recent legal, public policy and economic analysis becomes "the place we quarry the building blocks of our culture." 211 However, the construction of an affirmative idea of the public domain should always

\footnotetext{
${ }^{206}$ James Boyle, The Second Enclosure Movement and the Construction of the Public Domain, 66 LAW \& CONTEMP. PROBS. 62 (2003).

${ }^{207}$ L. RAY PATterson \& STANLEy W. LindBerg, The NATURE OF CoPyright: A LAW OF USERS' RIGHTS 50 (University of Georgia Press 1991).

${ }^{208} I d$. at $50-51$.

${ }^{209}$ See Lange, Reimagining The Public Domain, supra note 42, at 465, n.11 (for the "feeding" metaphor).

${ }^{210}$ Boyle, The Second Enclosure Movement and the Construction of the Public Domain, supra note 206, at 60 .

${ }^{211}$ James Boyle, The Public Domain: EnClosing the Commons of the Mind 41 (Yale Univ. Press 2009).
} 


Richmond Journal of Law \& Technology $\quad$ Volume XXIII, Issue 2

consider that the abstraction of the public domain is slippery. ${ }^{212}$ That affirmative notion must be embodied in a physical space that may be immediately protected and nourished. As Professor Lange puts it, "the problems will not be resolved until courts have come to see the public domain not merely as an unexplored abstraction but as a field of individual rights fully as important as any of the new property rights.,"213

[49] The modern public domain discourse owes much to the legal analysis of the governance of the commons, natural resources used by many individuals in common. Although the public domain and commons are diverse concepts, ${ }^{214}$ the similarities are many. Since the origin of the public domain discourse, the environmental metaphor has been largely used to refer to the cultural public domain. ${ }^{215}$ Therefore, the traditional environmental conception of the commons was ported to the cultural domain and applied to intellectual property policy issues. Environmental and intellectual property scholars started to look at knowledge as a

${ }^{212}$ See Ronan DeAZley, Rethinking COPYRight: History, THEORY, LANGUAGE 105 (Edward Elgar Pub. 2008).

${ }^{213}$ Lange, Recognizing the Public Domain, supra note 201, at 178.

${ }^{214}$ The main difference lies in the fact that a commons may be restrictive. The public domain is free of property rights and control. A commons, on the contrary, can be highly controlled, though the whole community has free access to the common resources. Free Software and Open Source Software are examples of intellectual commons. See YocHAI BenKler, The Wealth of Networks: How Social Production Transforms MARKETS AND FREEDOM 63-67 (Yale Univ. Press 2007). The source code is available to anyone to copy, use and improve under the set of conditions imposed by the General Public License. However, this kind of control is different than under traditional property regimes because no permission or authorization is required to enjoy the resource. These resources "are protected by a liability rule rather than a property rule." Lawrence Lessig, The Architecture of Innovation, 51 DUKE L. J. 1783, 1788 (2002). A commons is defined by the notions of governance and sanctions, which may imply rewards, punishment, and boundaries. See Wendy J. Gordon, Response, Discipline and Nourish: On Constructing Commons, 95 CORNELl L. ReV. 733, 736-49 (2010).

${ }^{215}$ See Mark Rose, Copyright and Its Metaphors, 50 UCLA L. ReV. 1, 8 (2002); see also William St Clair, Metaphors of Intellectual Property, in PRIVILEGE AND PROPERTY: ESSAYS ON THE HISTORY OF COPYRIGHT 369, 391-92 (Ronan Deazley et al. eds., Open Book Publishers 2010). 


\begin{tabular}{ll}
\hline Richmond Journal of Law \& Technology & Volume XXIII, Issue 2 \\
\hline
\end{tabular}

commons - a shared resource. In 2003, the Nobel Prize Elinor Ostrom and her colleague Charlotte Hesse discussed the applicability of their ideas on the governance and management of common pool resources to the new realm of the intellectual public domain. ${ }^{216}$ The following literature continued to develop the concept of cultural commons in the footsteps of the Ostrom's analyses. ${ }^{217}$ The application of the physical commons literature to cultural resources brings a shift in approach and methodology from the previous discourse of the public domain. This different approach has been described as follows:

[ $t$ ] he old dividing line in the literature on the public domain had been between the realm of property and the realm of the free. The new dividing line, drawn as a palimpsest on the old, is between the realm of individual control and the realm of distributed creation, management, and enterprise. 218

[50] Under this conceptual scheme, restraint on use may no longer be an evil, but a necessity of a well-run commons. The individual, legal, and market based control of the property regime is juxtaposed with the collective and informal controls of the well-run commons. ${ }^{219}$ The well-run

${ }^{216}$ See Charlotte Hess \& Elinor Ostrom, Ideas, Artifacts, and Facilities: Information as a Common-Pool Resource, 66 LAW \& CONTEMP. ProBs. 111, 111 (2003); see also Michael J. Madison, Brett M. Frischmann \& Katherine J. Strandburg, The University as Constructed Cultural Commons, 30 WASH. U. J. L. \& POL'Y 365, 403 (2009).

${ }^{217}$ See, e.g., Madison, Frischmann, \& Strandburg, supra note 216, at 373 (acknowledging that Ostrom's previous work laid the groundwork for their research); see also Elinor Ostrom \& Charlotte Hess, A Framework for Analyzing the Knowledge Commons, in Understanding Knowledge as a Commons: From Theory to Practice 41-81 (Charlotte Hess \& Elinor Ostrom eds., MIT Press 2007), http://surface.syr.edu/cgi/viewcontent.cgi?article $=1020 \&$ context=sul, archived at https://perma.cc/48HT-3YUE (using Ostrom's previous research as a base for new research throughout the chapter).

\footnotetext{
${ }^{218}$ Boyle, The Second Enclosure Movement and the Construction of the Public Domain, supra note 206, at 66.

${ }^{219}$ See James Boyle, Foreword: The Opposite of Property, 66 LAW \& CONTEMP. ProbS. 1, 8 (2003), http://scholarship.law.duke.edu/lcp/vol66/iss1/1/, archived at https://perma.cc/J4SL-YJU2.
} 
commons can avoid the "tragedy of the commons" without the need for single party ownership.

[51] The movement to preserve the environmental commons inspired a new politics of intellectual property. ${ }^{220}$ The environmental metaphor has propelled what can be termed as a cultural environmentalism. ${ }^{221}$ Several authors spearheaded by Professor James Boyle have cast a defense of the public domain on the model of the environmental movement. Morphing the public domain into the commons, and casting the defense of the public domain on the model of the environmental movement, has the advantage of embodying the public domain in a much more physical form, minimizing its abstraction and the related difficulty of actively protecting it. $^{222}$ The primary focus of cultural environmentalism is to develop a discourse that will make the public domain visible. ${ }^{223}$ Before the movement, the environment was invisible. Therefore, "like the environment", Boyle suggests by echoing David Lange, "the public domain must be 'invented' before it can be saved." 224 Today, the public domain has been "invented" as a positive concept and the "coalition that might protect it", evoked if not called into being by scholars more than a decade ago, is formed. ${ }^{225}$ Many academic and civic endeavors have joined and propelled this coalition. ${ }^{226}$ Civic advocacy of the public domain and

\footnotetext{
${ }^{220}$ See James Boyle, A Politics of Intellectual Property: Environmentalism for the Net?, 47 DukE L. J. 87, 110 (1997).

${ }^{221}$ See James Boyle, Cultural Environmentalism and Beyond, 70 LAW \& CONTEMP. PROBS. 5, 6 (2007).

222 See Boyle, The Public Domain: Enclosing the Commons of the Mind, supra note 211 , at 180 .

${ }^{223}$ See id. at $241-42$.

${ }^{224}$ Boyle, The Second Enclosure Movement and the Construction of the Public Domain, supra note 206, at 52.

225 Boyle, A Politics of Intellectual Property: Environmentalism for the Net?, supra note 220 , at 113 .

${ }^{226}$ See COMMUNIA, Survey of Existing Public Domain Competence Centers, Deliverable No. D6.01 (Draft, September 30, 2009) (survey prepared by Federico
} 


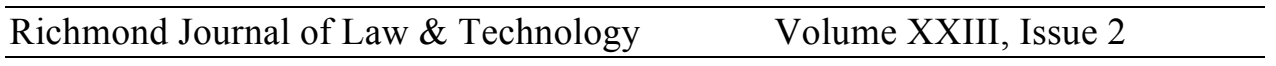

access to knowledge has also been followed by several institutional variants, such as the World Intellectual Property Organization's "Development Agenda." 227 Recommendation 20 of the Development Agenda endorses the goal "[t]o promote norm-setting activities related to IP that support a robust public domain in WIPO's Member States." 228 Europe put together a diversified network of projects for the protection and promotion of the public domain and open access. ${ }^{229}$ As a flagship initiative, the European Union has promoted COMMUNIA, the European Thematic Network on the Digital Public Domain. ${ }^{230}$ Several COMMUNIA

Morando and Juan Carlos De Martin for the European Commission) (on file with the author), https://www.yumpu.com/en/document/view/17424248/survey-of-existingpublic-domain-competence-centers-communia/6, archived at https://perma.cc/B745GH72 (reviewing the current landscape of European competence and excellence centers that focus on the study of the public domain).

${ }^{227}$ See WIPO, DEVELOPMENT AgENDA FOR WIPO, supra note 152; see also Severine Dusollier, Scoping Study on Copyright and the Public Domain, WIPO (prepared for the Word Intellectual Property Organization) (May 7, 2010).

${ }^{228}$ Chair of the Provisional Committee on Proposals Related to a WIPO Development Agenda (PCDA), Initial Working Document for the Committee on Development and Intellectual Property (CDIP), WIPO (Mar. 3, 2008), $\mathrm{http} / / / \mathrm{www} . w i p o . i n t / m e e t i n g s / e n / d o c \_d e t a i l s . j s p ? d o c \_i d=92813$, archived at . https://perma.cc/98AG-HNHL.

${ }^{229}$ Compare COMMUNIA FINAL REPORT, supra note 69 (launching programs together with Communia, as part of the i2010 policy strategy); with LAPSI: The European Thematic Network on Legal Aspects of Public Sector Information, EUROPEAN COMMISSION (Dec. 17, 2012), https://joinup.ec.europa.eu/community/epractice/case/lapsi-european-thematic-networklegal-aspects-public-sector-information, archived at https://perma.cc/6VEH-6MEU; and Digital Repository Infrastructure Vision for European Research, CORDIS (last visted Jan. 30, 2017), http://cordis.europa.eu/project/rcn/86426_en.html, archived at https://perma.cc/P37J-PNQU; and ARROW, supra note 78; and DARIAH, Digital Research Infrastructure for the Arts and Humanities, http://www.dariah.eu, archived at https://perma.cc/Q2NN-N5EZ (aiming to enhance and support digitally-enabled research across the humanities and the arts).

${ }^{230}$ See Communia, The European Thematic Network on the Digital Public Domain, COMMUNIA, http://communia-project.eu, archived at https://perma.cc/LR3B-JNHJ; see also Giancarlo F. Frosio, Communia and the European Public Domain Project: A Politics of the Public Domain, in The Digital Public Domain: Foundations For AN Open Culture (Juan Carlos De Martin \& Melanie Dulong de Rosnay eds., OpenBooks 


Richmond Journal of Law \& Technology $\quad$ Volume XXIII, Issue 2

members embodied their vision in the Public Domain Manifesto. ${ }^{231}$ In addition, other European policy statements endorsed the same core principles of the Public Domain Manifesto. The Europeana Foundation has published the Public Domain Charter to stress the value of public domain content in the knowledge economy. ${ }^{232}$ The Free Culture Forum released the Charter for Innovation, Creativity and Access to Knowledge, pleading for the expansion of the public domain, the accessibility of public domain works, the contraction of the copyright term, and the free availability of publicly funded research. ${ }^{233}$ The Open Knowledge Foundation launched the Panton Principles for Open Data in Science to endorse the concept that "data related to published science should be explicitly placed in the public domain." 234

[52] The focus of cultural environmentalism has been magnified in online commons and the Internet as the "über-commons - the grand infrastructure that has enabled an unprecedented new era of sharing and collective action. ${ }^{, 235}$ In the last decade, we have witnessed the emergence

Publishers 2012).

${ }^{231}$ See The Public Domain Manifesto, The Public Domain Manifesto (2009), $\mathrm{http} / / /$ publicdomainmanifesto.org/manifesto.html, archived at https://perma.cc/79YYPHTD.

${ }^{232}$ See generally The Europeana Public Domain Charter, $\mathrm{http} / / / \mathrm{www}$.europeana.eu/portal/en/rights/public-domain-charter.html, archived at https://perma.cc/KX8M-VVV6 (advocating for the public's interest in maintaining access to Europe's cultural and scientific heritage).

${ }^{233}$ See Charter for Innovation Creativity and Access to Knowledge, FREE CULTURE FORUM, http://fcforum.net, archived at https://perma.cc/N9N4-D93F (last visited Jan. 30, 2017).

${ }^{234}$ John Dupuis, Panton Principles: Principles for Open Data in Science, SCIENCE BLOGS (Feb. 22, 2010), http://scienceblogs.com/confessions/2010/02/22/pantonprinciples-principles-f/, archived at https://perma.cc/27WH-ALQE.

${ }^{235}$ David Bollier, The Commons as a New Sector of Value-Creation: It's Time to Recognize and Protect the Distinctive Wealth Generated by Online Commons, ON THE CoMmons (Apr. 22, 2008), http://www.onthecommons.org/commons-new-sector-valuecreation, archived at https://perma.cc/9QBP-JZ5Z. 
of a "single intellectual movement, centered on the importance of the commons to information production and creativity generally, and to the digitally networked environment in particular."236 According to David Bollier, the commoners have emerged as a political movement committed to freedom and innovation. ${ }^{237}$ The "commonist" movement created a new order that is embodied in countless collaborative online endeavors.

[53] The emergence and growth of an environmental movement for the public domain and, in particular, the digital public domain, is morphing the public domain into our cultural commons. We must look at it as a shared resource that cannot be commodified, much like our air, water, and forests. As with the natural environment, the public domain and the cultural commons that it embodies must enjoy a sustainable development. As with our natural environment, the need to promote a "balanced and sustainable development" of our cultural environment is a fundamental right that is rooted in the Charter of Fundamental Rights of the European Union. ${ }^{238}$ Overreaching property theory and overly protective copyright law disrupt the delicate tension between access and protection. Unsustainable cultural development, enclosure and commodification of our cultural commons will produce cultural catastrophes. As unsustainable environmental development has polluted our air, contaminated our water, mutilated our forests, and disfigured our natural landscape, unsustainable cultural development will outrage and corrupt our cultural heritage and information landscape.

\section{CONCLUSIONS}

[54] I would like to conclude my review of this movement "resisting the resistance" to the Digital Revolution by sketching out a roadmap for reform that builds upon its vision. This roadmap reshapes the interplay between community, law, and market to envision a system that may fully

\footnotetext{
${ }^{236}$ BENKLER, supra note 214 at I.

${ }^{237}$ See David Bollier, Viral Spiral: How the Commoners Built a Digital RePublic OF THEIR OWN 3-14, (New Press 2009).

${ }^{238}$ See Charter of Fundamental Rights of the European Union, December 18, 2000, 2000 O.J. (C364) 1, 8, 37.
} 
Richmond Journal of Law \& Technology $\quad$ Volume XXIII, Issue 2

exploit the digital opportunity and looks to the history of creativity as a guide. ${ }^{239}$ This proposal revolves around the pivotal role of the users in a modern system for enhancing creativity. The coordinates of the roadmap correlate to four different but interlinked facets of a healthy creative paradigm: namely, (a) the necessity to rethink users' rights, in particular users' involvement in the legislative process; (b) the emergence of a politics of the public domain, rather than a politics of intellectual property; (c) the need to make cumulative and transformative creativity regain its role through the re-definition of the copyright permission paradigm; and (d) the transition to a consumer gift system or user patronage, through digital crowd-funding.

[55] The roadmap for reform emphasizes the role of the users. The Internet revolution is a bottom-up revolution. User-based culture defines the networked society, together with a novel concept of authorship mingling users and authors together. Therefore, the role of users in our legislative process and the relevance of user rights should be reinforced. So far, users have had very limited access to the bargaining table when copyright policies had to be enacted. This is due to the dominant mechanics of lobbying that largely excludes users from any policy decisions. This led to the implementation of a copyright system that is strongly protectionist and pro-distributors. In particular, the regulation of the Internet and the solutions given to the dilemmas posed by digitalization may undermine the potential of this momentous change and limit positive externalities for users.

[56] In the networked, peer, and mass productive environment, creativity seeks a politics of inclusive rights, rather than exclusive. This is a paradigm shift that would re-define the hierarchy of priorities by

\footnotetext{
${ }^{239}$ Individual components of this roadmap for reform have been described in previous works of mine - to which I refer in this article. A more detailed review of this roadmap for reform - with each component of the proposal acting as a pillar for a metaphorical temple dedicated to the enhancement of creativity - will be the subject of Chapter 12 from my forthcoming book. Giancarlo F. Frosio, Rediscovering Cumulative Creativity: From the Oral-Formulaic Tradition to Digital Remix: Can I Get a Witness? (Edward Elgar, forthcoming 2017) (expanding on Frosio, Frosio, Rediscovering Cumulative Creativity from the Oral Formulaic Tradition to Digital Remix: Can I Get a Witness?, supra note 19).
} 


\begin{tabular}{ll}
\hline Richmond Journal of Law \& Technology & Volume XXIII, Issue 2 \\
\hline
\end{tabular}

thinking in terms of "cultural policy" and developing a political policy of the public domain, rather than a political policy of intellectual property. Before the recognition of any intellectual property interests, a politics of the public domain must set up the "deliberate recognition of individual rights in the public domain." ${ }^{240}$ It must provide positive protection of the public domain from appropriation. A politics of the public domain would reconnect policies for creativity with our past and our future, looking back at our tradition of cumulative creativity and looking forward at networked, mass collaborative, user-generated creativity. ${ }^{241}$

[57] In order to reconnect the creative process with its traditional cumulative and collaborative nature, a politics of inclusive rights and a politics of the public domain seek the demise of copyright exclusivity. ${ }^{242}$ In my roadmap for reform, I argue for the implementation of additional mechanisms to provide economic incentives to create, such as a liability rule integrated into the system and an apportionment of profits. A politics of inclusivity would de-construct the post-romantic paradigm that overemphasized creative individualism and absolute originality in order to adapt policies to networked and user-generated creativity.

[58] Finally, I draw a parallel between traditional patronage, corporation patronage, and neo-patronage or user patronage as a reconceptualization of a patronage system in line with the exigencies of an interconnected digital society. ${ }^{243}$ In the future, support for creativity may

\footnotetext{
${ }^{240}$ Lange, Reimagining the Public Domain, supra note 42, at 463.

${ }^{241}$ See COMMUNIA FinAL REPORT, supra note 69 (further discussing the politics of the public domain).

${ }^{242}$ This proposal — and the historical interdisciplinary research that serves as a background-has been discussed at length in previous works of mine to which I refer. See Giancarlo F. Frosio, A History of Aesthetics from Homer to Digital Mash-ups: Cumulative Creativity and the Demise of Copyright Exclusivity, 9(2) LAW AND HuMANITIES 262 (2015), http://www.tandfonline.com/doi/full/10.1080/17521483.2015.1093300, archived at https://perma.cc/YEC3-34FK; see also Murray, supra note 9.

${ }^{243}$ For a full discussion of the idea of user patronage - and a review of the economics of creativity form a historical perspective-See Frosio, Rediscovering Cumulative Creativity
} 
increasingly derive from a direct and unfiltered exchange between authors and the public, who would become the patrons of our creativity. Remuneration through attribution, self-financing through crowd-funding, ubiquity of digital technology, and mass collaboration will keep the creative process in motion. This market transformation will facilitate a direct, unrestrained "discourse" between creators and the public. Yet, the role of distributors will be redefined and may partially disappear, making the transition long and uncertain.

from the Oral Formulaic Tradition to Digital Remix: Can I Get a Witness? supra note 19 at 376-90. 